\title{
Callous-unemotional traits as a cross-disorders construct
}

\author{
Pierre C. M. Herpers • Nanda N. J. Rommelse • \\ Daniëlle M. A. Bons • Jan K. Buitelaar • \\ Floor E. Scheepers
}

Received: 25 July 2011/Accepted: 14 April 2012/Published online: 9 May 2012

(C) The Author(s) 2012. This article is published with open access at Springerlink.com

\begin{abstract}
Purpose Callous-unemotional (CU) traits are currently viewed as the defining signs and symptoms of juvenile psychopathy. It is unclear, however, whether CU traits have validity only in the context of conduct disorder (CD) as proposed by Frick and Moffitt (A proposal to the DSM$\mathrm{V}$ childhood disorders and the ADHD and disruptive behavior disorders work groups to include a specifier to the diagnosis of conduct disorder based on the presence of callous-unemotional traits, American Psychiatric Association, Washington, DC, 2010), or also outside CD, either in combination with other forms of psychopathology or as a stand-alone construct.

Methods The current review systematically studied the existent literature on $\mathrm{CU}$ traits in juveniles to examine their validity inside and outside $\mathrm{CD}$ according to the framework regarding the validity of a psychiatric diagnosis provided by Robins and Guze (Am J Psychiatry 126:983-987, 1970).
\end{abstract}

P. C. M. Herpers $(\bowtie) \cdot$ N. N. J. Rommelse .

D. M. A. Bons · J. K. Buitelaar

Karakter Child and Adolescent Psychiatry University Centre,

Radboud University Nijmegen Medical Centre,

Reinier Postlaan 12, 6525 GC Nijmegen, The Netherlands

e-mail: p.herpers@karakter.com

N. N. J. Rommelse

e-mail: n.lambregts-rommelse@psy.umcn.nl

D. M. A. Bons

e-mail: d.bons@karakter.com

J. K. Buitelaar

e-mail: j.buitelaar@psy.umcn.nl

F. E. Scheepers

Department of Child and Adolescent Psychiatry,

University Medical Centre Utrecht, P.O. Box 85500,

3508 GA Utrecht, The Netherlands

e-mail: f.e.scheepers-2@umcutrecht.nl
Results Inside youth with conduct problems, and CD specifically, it seems that CU traits meet the Robins and Guze criteria. As many of the reviewed studies included youth with ODD and ADHD as well, there are indications the same might be true for ODD and ADHD, although probably to a lesser extent. In other disorders, CU traits may be present as well, but their role is not firmly established. As stand-alone construct, data are lacking or are scarce on all of the above-mentioned criteria.

Conclusions $\mathrm{CU}$ traits are a useful specifier in $\mathrm{CD}$, and possibly also in disruptive behaviour disorders (DBDs) more generally. High CU traits outside DBDs exist but it is as yet unknown if there is a clinical need for defining $\mathrm{CU}$ traits as a stand-alone construct.

Keywords Callous-unemotional traits · Juvenile psychopathy $\cdot$ Conduct disorder · Validity

\section{Introduction}

There is an increasing interest in the moderating role psychopathic traits may play regarding long-term outcome and treatment effectiveness of disruptive behaviour [1-3]. Specifically, there is a widely held belief that psychopathy has a poor outcome and is untreatable, although it seems more appropriate to state that a subgroup of patients with disruptive behaviour who portray psychopathic traits may require different treatment than patients with disruptive behaviour without these traits [2].

Although the history of the concept of psychopathy goes back to the nineteenth century $[4,5]$, today's view on psychopathy is substantially based on Cleckley's work, first published in 1941 [6], in which psychopathy is seen as a personality disorder. In recent literature, different aspects 
of psychopathy have been emphasized, such as: (1) disinhibition, poor impulsive regulation and the inclination to immediate gratification; (2) boldness, bravery, and thrill and adventure seeking; and (3) meanness, callousness and coldheartedness [7, 8]. There is now consensus that the presence of impulsive externalizing behaviour is not sufficient for a diagnosis of psychopathy but that boldness and/or meanness are the more typical characteristics. Particularly meanness is viewed by many experts as the core component of psychopathy. Frequently described symptoms of this core component are: lacking guilt and empathy, being very egocentric, showing callous use of others for ones own gain, and lacking normal emotionality, especially in showing a lack of anxiety. These symptoms have been known as callous-unemotional (CU) traits [1].

Regarding CU traits specifically, reviews have been published paying attention to the aetiology [9] and diagnostic value [10-12]. Some reviews have specifically focused on the conceptualization of $\mathrm{CU}$ traits in youth in relation to conduct problems [13-16], which is of importance because the aetiology and symptom presentation of a disorder in youth and adults may be different and need specific attention $[5,17,18]$ and $\mathrm{CU}$ traits in antisocial youth seem to designate a distinct group that might develop into adult psychopathy. Furthermore, early detection might result into early intervention strategies preventing the development of adult psychopathy and antisocial behaviour. However, common to these reviews is that their focus is on the role of CU traits as a subtype of conduct disorder (CD) as proposed by the ADHD and Disruptive Behaviour Disorders Work Group for DSM-V [19] (see Table 1). Furthermore, in adults, subtypes of psychopathy can be distinguished. One of these subtypes is characterized by relatively high scores on deficient affective experience (comparable to $\mathrm{CU}$ traits) and low on antisocial behaviour [20]. Therefore, several questions remain: do CU traits represent a discrete or dimensional entity; are $\mathrm{CU}$ traits indeed related to $\mathrm{CD}$ only; does the psychopathological syndrome of $\mathrm{CU}$ traits show sufficient validity when assessed clinically (cf. [21])?

By following the set of specific criteria for validation of psychiatric constructs, as proposed by Robins [22] and modified by Faraone [23], the current review aimed to contribute to the existing literature by taking a broader perspective on the nosological status of $\mathrm{CU}$ traits by focusing on their validity as a potential classifier for $\mathrm{CD}$, other disorders than just $\mathrm{CD}$ and as a stand-alone construct (i.e. a separate DSM-diagnosis). These criteria are: (a) the construct has a consistent pattern of signs and symptoms, (b) the construct is dissociable from other related diagnoses, (c) the construct has a characteristic course and outcome, (d) the construct shows evidence of heritability from family and genetic studies, (e) data from laboratory studies demonstrate neurobiological and neuropsychological correlates of the construct, and (f) the construct shows a characteristic response to treatment. Since the Robins and Guze criteria were published more than 40 years ago, they may seem dated. Yet, they have been labelled as golden standard for establishing diagnostic validity, thus providing opportunity for psychiatric diagnoses to be defined as 'real entities' [24]. Recent papers have used these criteria for disruptive behaviour disorders [23, 25]. Yet, a few critical remarks can be made. The Robins and Guze criteria partially overlap with the set of criteria for construct validity, as formulated by Cronbach and Meehl [26], which has been of great importance as well [27]. Cronbach and Meehl [26] place an important emphasis on the nomological network, meaning that a construct needs to 'function' according to laws in which the construct occurs, while this criterion is not needed in the Robins and Guze criteria. However, the purpose of our paper was not to either investigate or extend the nomological network

Table 1 Proposed specifier for callous-unemotional traits in the DSM-V

1. Meets full criteria for conduct disorder

2. Shows two or more of the following characteristics persistently over at least 12 months and in more than one relationship or setting.The clinician should consider multiple sources of information to determine the presence of these traits, such as whether the person self-reports them as being characteristic of him or herself and if they are reported by others (e.g. parents, other family members, teachers, peers) who have known the person for significant periods of time

Lack of remorse or guilt: does not feel bad or guilty when he/she does something wrong (except if expressing remorse when caught and/or facing punishment)

Callous-lack of empathy: disregards and is unconcerned about the feelings of others

Unconcerned about performance: does not show concern about poor/problematic performance at school, work, or in other important activities.

Shallow or deficient affect: does not express feelings or show emotions to others, except in ways that seem shallow or superficial (e.g. emotions are not consistent with actions; can turn emotions "on" or "off" quickly) or when they are used for gain (e.g. to manipulate or intimidate others)

http://www.dsm5.org/ProposedRevisions/Pages/proposedrevision. aspx?rid=424 
regarding $\mathrm{CU}$ traits, but to investigate the diagnostic validity of CU traits. Therefore, the Robins and Guze criteria seemed to fit better for our purposes. Another critical remark can be made regarding the fact that the Robins and Guze criteria do not seem to take comorbidity into account, yet comorbidity is the rule rather than the exception in mental disorders [28]. Therefore, it is relevant to clarify the distinctiveness of the relationship between $\mathrm{CU}$ traits and 'established' mental disorders. To our knowledge, this review is the first to apply these criteria to the construct of $\mathrm{CU}$ traits in youth.

A PubMed search was performed, focusing on research articles published between 1980 and December 2011, addressing CU traits as well as juvenile psychopathy, and review articles that appeared to be key articles (search terms: juvenile psychopathy and callous unemotional traits). Within the articles that were believed to be relevant, we have searched for additional literature. Studies had to use assessment instruments that quantified psychopathic and/or CU traits and had to have included comparison groups. CU traits were operationalized as those subdimensions of psychopathy which include symptoms such as callousness, shallowness and lack of empathy. This led to an initial 981 publications of which 206 (including 6 reviews) were eligible for this review. Findings are reported primarily in a qualitative manner.

\section{Criterion 1: Do CU traits have a consistent pattern of signs and symptoms?}

The first criterion that must be met in order to consider CU traits as a construct inside or outside CD is that a consistent pattern of signs and symptoms must demarcate it from other disorders and from psychiatric wellness [22, 23]. However, there is no universal agreement with respect to how to best measure $\mathrm{CU}$ traits. $\mathrm{CU}$ traits seem to be a diagnostic construct that is still in a developmental stage.

The construct of CU traits has been developed on the basis of the concept of psychopathy. In the past 20 years, there has been an increasing interest in the concept of juvenile psychopathy and to our knowledge, at least 17 instruments have been developed which aim directly at assessing either psychopathic or $\mathrm{CU}$ traits, and which have been used in juvenile populations (see Table 2). The Psychopathy Checklist: Youth Version (PCL:YV; [29]) seems to be the first assessment tool that specifically focused on psychopathy in youth. Others followed and the versions for self-report were developed, leading to instruments such as the Antisocial Process Screening Device (APSD; [30]), and the Youth Psychopathic Traits Inventory (YPI; [31]). For reviews, we refer to $[16,32]$.

Trying to fractionate the concept of juvenile psychopathy, factor analyses have been applied on various
Table 2 Assessment instruments for measuring psychopathic traits in youth

\begin{tabular}{llll}
\hline Full name & Abbreviation & Reference & Rater \\
\hline Psychopathy Checklist: revised & PCL-R & {$[228]$} & Clinician rated \\
Self-Report Psychopathy Scale: II & SRP-II & {$[229]$} & Self-report \\
Psychopathy Checklist: Screening Version & PCL:SV & {$[230]$} & Clinician rated \\
Survey of Attitudes and Life Experiences & SALE & {$[231]$} & Self-report \\
Childhood Psychopathy Scale & CPS & {$[232]$} & Clinician rated \\
Psychopathy Content Scale & PCS & {$[105]$} & Self-report \\
Psychopathy Screening Device & PSD & {$[233]$} & Self-report \\
Antisocial Process Screening Device & APSD & {$[30]$} & Self-report \\
& & & Teacher-report \\
& & & Parent-report \\
Youth Psychopathy traits Inventory & YPI & {$[31]$} & Self-report \\
Psychopathy Checklist: Youth Version & PCL:YV & {$[29]$} & Clinician rated \\
Inventory of Callous-Unemotional traits & ICU & {$[53]$} & Self-report \\
& & & Teacher-report \\
Multidimensional Personality Questionnaire & MPQ & {$[141]$} & Parent-report \\
Minnesota Temperament Inventory & MTI & {$[136]$} & Self-report \\
Social and Emotional Detachment Questionnaire & SEDQ & {$[74]$} & Self-report \\
NEO Psychopathy Resemblance Index & NEO PRI & {$[234]$} & Parent-report \\
Five Factor Model Psychopathy count & FFM PP count & {$[54]$} & Self-report \\
Psychopathic Personality Inventory Short-Form & PPI-SF & {$[235]$} & Self-report \\
\hline
\end{tabular}


instruments, mostly the PCL:YV, on the basis of scores obtained in community samples as well as in juvenile offenders. Although two-factor models [33-39], a fourfactor model (e.g. [40-43]) and a five-factor model [44] have been proposed as underlying psychopathy with confirmatory factor analyses, a three-factor model seems to fit best (e.g. [44-51]). The three-factor model consists of factors which can be labelled as: (a) sensation seeking behaviour, (b) arrogant/deceptive interpersonal style, and (c) callous-unemotional traits. Discussion remains whether a fourth factor, labelled antisocial-aggressive behaviour, should be added [41, 42, 46].

The findings from these factor analytic studies are reasonably consistent in finding a distinct factor including lack of empathy, shallow affect and superficial interpersonal relationships, even though the factors are not always labelled similarly and their content may vary somewhat between different studies. This factor, with time increasingly called callous-unemotional traits, is consistently present in all models. This factor can be assessed reliably as from an age of 4 years [44]. Recently, a promising attempt was made to diagnose $\mathrm{CU}$ traits in preschoolers [52].

In youth, $\mathrm{CU}$ traits were increasingly seen as having incremental validity regarding diagnosing youth with conduct problems [19], which led to the development of the Inventory of Callous-Unemotional traits (ICU) [53], for assessment of $\mathrm{CU}$ traits specifically. Validation studies are promising, showing good internal consistency (Cronbach's $\alpha=0.69-0.83$; [54-58] and concurrent validity $\left(r^{2}=0.45-0.68\right.$ between ICU and APSD, and CPS) [57, 58]. However, other expressions of validity (e.g. temporal stability, interrater reliability) of the ICU specifically have to be established yet.

The current proposal to include a specifier for CU traits to conduct disorder in the DSM-5 formulates four criteria, of which two have to be met to assess CU traits (Table 1). For the development of this specifier, we refer to [19]. Internal consistency was shown to be moderate (Cronbach's $\alpha=0.56$ ), yet many questions remain as it is unknown how well clinical validity is [19]. Thus, it seems that though CU traits as a construct show good 'face validity', the consistency of signs and symptoms within and specifically outside $\mathrm{CD}$ needs further evaluation.

\section{Criterion 2: Are CU traits dissociable from other related diagnoses?}

A second criterion that must be met in order for CU traits to be considered as a valid nosological construct is its relative distinctiveness from other (related) DSM diagnoses. How often do high CU traits co-occur with CD? Are
$\mathrm{CU}$ traits significantly more often linked to the presence of $\mathrm{CD}$ than to other disorders as ODD, ADHD, and ASD? Can high $\mathrm{CU}$ traits exist in the absence of other diagnostic entities, as CD, ODD, ADHD, ASD, personality disorder, mental retardation, and substance abuse (see Table 3)?

\section{Disruptive behaviour disorders}

Several epidemiologic studies investigated the prevalence of CU traits (see Table 4). CD was found to be present in $2 \%$ of community children [59]. 32-46.1\% of community youth with $\mathrm{CD}$ was found to score high on $\mathrm{CU}$ traits [59, 60]. In the no CD group, 2.9-7\% scored high on CU traits $[59,60]$. Comparable overall conclusions can be drawn from other epidemiological studies [19, 39, 61, 62] as well as a factor analytic study [35]. These studies imply that CU traits show overlap with $\mathrm{CD}$, but are not interchangeable. Because of the upcoming CU traits specifier in the DSM-5, it is important to notice that numerous studies reported on a more pervasive and severe pattern of antisocial behaviour in $\mathrm{CD}$ patients with $\mathrm{CU}$ traits compared to those without CU traits. For reviews we refer to, e.g. [13, 15, 63], with recent publications confirming these observations [64-73].

Less is known about the possibility to use CU traits as a classifier in ODD. On the one hand, correlations between CU traits and ODD, and CD were found to be similar [74]; and $\mathrm{CU}$ traits have been described in youth with ODD only [75], suggesting CU traits may indeed be a useful specifier for ODD. On the other hand, CU traits are much more prevalent in CD than ODD [59, 76], making the clinical utility of a specifier in ODD less obvious. Further

Table 3 Relationship between CU traits and specific diagnoses

\begin{tabular}{lll}
\hline Diagnosis & Support & No support \\
\hline Conduct disorder & $\begin{array}{c}\text { Core references: } \\
{[35,44,59]}\end{array}$ & \\
& Reviews: [15, 63] & \\
& {$[75]$} & {$[59,74,76]$} \\
Oppositional-defiant disorder & {$[236]$} & {$[55,87-91]$} \\
Personality disorder & {$[79,80]$} & {$[81-85,119]$} \\
Attention-deficit/hyperactivity & & {$[81,96-99]$} \\
disorder & & {$[101-105]$} \\
Mental retardation & & {$[93,94]$} \\
Substance abuse & & \\
Autism spectrum disorder & & {$[33,114]$} \\
Anxiety disorder & & \\
Self-reported anxiety $\downarrow$ & {$[106,107,112,113]$} \\
Parent-rated anxiety $\downarrow$ & {$[108-110]$} & {$[81]$} \\
Teacher-rated anxiety $\downarrow$ & {$[110]$} & {$[116]$} \\
Clinician-rated anxiety $\downarrow$ & & \\
Mood disorder & &
\end{tabular}

$\downarrow$, decreased in the presence of high CU traits 
Table 4 Prevalence of CU traits

\begin{tabular}{|c|c|c|c|c|c|c|c|}
\hline Study & Sample & Male (\%) & CD-only (\%) & $\mathrm{CD}+\mathrm{CU}(\%)$ & CU-only (\%) & $\mathrm{CP}+\mathrm{CU}(\%)$ & CP-only (\%) \\
\hline [62] & Community & 51 & n.i. & n.i. & 7.2 & 5.6 & 7.9 \\
\hline \multirow[t]{2}{*}{ [19] } & Community & $51-76$ & n.i. & n.i. & $7-11$ & n.i. & \\
\hline & Incarderated & $51-76$ & n.i. & $12-33$ & n.i. & n.i. & n.i. \\
\hline \multirow[t]{2}{*}[60]{} & Community & 57 & \multicolumn{5}{|c|}{$\begin{array}{l}32 \% \text { of those with CD met criteria for specifier for CU traits } \\
7 \% \text { of those without } \mathrm{CD} \text { met criteria for specifier for } \mathrm{CU} \text { traits }\end{array}$} \\
\hline & Clinic-referred & 60 & \multicolumn{5}{|c|}{$\begin{array}{l}50 \% \text { of those with CD met criteria for specifier for CU traits } \\
32 \% \text { of those without } \mathrm{CD} \text { met criteria for specifier for } \mathrm{CU} \text { traits }\end{array}$} \\
\hline [61] & Community & 0 & \multicolumn{5}{|c|}{$\begin{array}{l}40.5 \% \text { reported at least once above } 1 \mathrm{SD} \text { on } \mathrm{CU} \text { traits over a 4-year period } \\
65.5 \% \text { of the group meeting criteria for } \mathrm{CD} \text { had high } \mathrm{CU} \text { scores } \\
44.3 \% \text { of the group with high } \mathrm{CU} \text { traits met criteria for } \mathrm{CD}\end{array}$} \\
\hline [59] & Community & - & 1.1 & 0.9 & 2.9 & n.i. & n.i. \\
\hline \multirow[t]{2}{*}{ [39] } & Community & 49 & n.i. & n.i. & 3.8 & n.i. & \\
\hline & Incarcerated & 42 & n.i. & n.i. & 8.9 & n.i. & \\
\hline
\end{tabular}

$C D$ conduct disorder, $C P$ conduct problems, $C U$ callous-unemotional traits, $S D$ standard deviation, n.i. no information given

investigation regarding the relationship between $\mathrm{CU}$ traits and ODD specifically seems to be needed.

$\mathrm{CD}$ and ODD are both frequently comorbid with ADHD, making it relevant to examine the relationship between $\mathrm{CU}$ traits and ADHD. It has been argued [77] and demonstrated [78-80] that a subgroup of children with conduct problems and hyperactivity, impulsivity and attention problems (HIA-CP) resemble adult psychopathy. In contrast, several studies could not ascertain the relationship between $\mathrm{CU}$ traits and ADHD, when controlling for the presence of conduct problems [81-85].

Taken together, the presence of CU traits together with $\mathrm{CD}$ seems to lead to a specific syndrome with more severe antisocial behaviour, leading the DSM-5 workgroup to conclude CU traits are a useful specifier for CD. However, there are serious indications that $\mathrm{CU}$ traits are also present in youth with either ODD or ADHD without $\mathrm{CD}$, albeit less prevalent, making the clinical utility of a specifier in ODD or ADHD less obvious. Regarding the validity of CU traits as a stand-alone construct, findings are scarce. High CU traits without disruptive behaviour do appear to exist based on several epidemiologic studies.

\section{Personality disorder}

It has been argued that adult psychopathy is not only related to personality, but also that it is personality [86]. Much research in adult psychopathy has used personality questionnaires for delineating signs and symptoms of psychopathy. Findings show a strong negative relationship between psychopathy and agreeableness (expressing concern about interpersonal relationships and strategies) and conscientiousness (expressing ability to plan, organize, and complete behavioural tasks) [86]. As such, the question is whether CU traits in adolescents and adults are interchangeable with the personality disorders as described in DSM-IV-TR.

Several studies have investigated the relationship between $\mathrm{CU}$ traits and personality traits. These found an inverse association between $\mathrm{CU}$ traits with both agreeableness and conscientiousness [55, 87-89]. Furthermore, $\mathrm{CU}$ traits were found to be negatively associated with stress reaction (expressing reaction to distress, anxiety) and positively associated to aggression (expressing irritability, aggression) [90], and that CU traits in youth were not specifically related to narcissism [91]. Thus, these studies suggest $\mathrm{CU}$ traits to be related to certain personality dimensions/traits that can be apparent before the age of 18 years. However, none of these studies supports $\mathrm{CU}$ traits to be seen as equal to personality disorders.

Since personality disorders have their onset mostly in adolescence, and persist into adulthood [92], a next question is whether $\mathrm{CU}$ traits are predictors of adult personality disorders. However, we could not find any studies addressing this issue.

Autism spectrum disorder and mental retardation

Because autism spectrum disorder (ASD) and mental retardation are both related to lower levels of empathy and self-reflection, it is possible that both are related to higher levels of CU traits. In youth with ASD, it was found that the correlation between severity of $\mathrm{CU}$ traits and ASD traits was extremely low, and callous antisocial behaviour did not appear to result from those cognitive deficits that are core to autistic disorders, such as 'mindblindness' and executive dysfunction [93]. Furthermore, boys with conduct problems and high $\mathrm{CU}$ traits were found to have 
dysfunctional affective empathy, but not cognitive empathy. The contrary was found in boys with ASD [94, 95]. Less is known about the relationship between intelligence (IQ) and CU traits. Some studies report no relationship [79, $96,97]$. Others report that youth with conduct problems and CU traits have a higher IQ [98] or in contrast a lower IQ [99] compared to youth with conduct problems without $\mathrm{CU}$ traits. Recently, CU traits were related to poor reading comprehension when controlling for IQ [79, 100]. These results suggest that autism and mental retardation are probably not related to $\mathrm{CU}$ traits, although both might hypothetically influence the phenotypic expression of $\mathrm{CU}$ traits.

\section{Substance abuse}

Although the presence of psychopathic traits in substanceabusing adolescents is related to a higher level of alcoholand drugs-related problems, there are no indications that $\mathrm{CU}$ traits in youth are the result of alcohol or drug abuse [101-105].

\section{Anxiety and mood disorders}

As CU traits are associated with shallow affect and low fearfulness, anxiety was investigated in ten studies, of which seven controlled for conduct problems [81, 106-111]. CU traits mostly show a significant inverse relationship with subjective ratings of anxiety, either self-, parent-, teacheror clinician reported [106-113], although this might account only for those children that perceived low levels of parental warmth/involvement [109]. Nevertheless, these correlations are not always found [33, 81, 114]. Mood disorders have been investigated scarcely. In a long-term follow-up study of about 10 years, mood problems in childhood were found to be predictive for $\mathrm{CU}$ traits in adulthood [115]. A recent study [116] investigated the relationship between $\mathrm{CU}$ traits and suicidality, and found no relationship in boys but an inverse relationship in girls, implying a protective role for $\mathrm{CU}$ traits. However, this latter study did not control for either conduct problems or CD. Therefore, there is insufficient information to draw conclusions regarding the relationship between $\mathrm{CU}$ traits and mood disorders.

\section{Criterion 3: Do CU traits have a characteristic course and outcome?}

A third criterion for $\mathrm{CU}$ traits to meet the standards for a valid disorder is that they have a characteristic, and therefore predictable, course and outcome. This means that assessment of the diagnosis should lead to a clear prognosis. Especially important is the question: when $\mathrm{CU}$ traits are a subtype of $\mathrm{CD}$, how strong do $\mathrm{CU}+$ and $\mathrm{CU}-$ forms of $\mathrm{CD}$ differentiate from each other in external characteristics such as course and prognosis (see Table 5)?

Both short-term studies (up to 4 years) $[44,61,110$, $112,117-124]$ and long-term studies (4-15 years) [115, 125-129] found CU traits to be predictive of more problematic behaviour. Studies investigating the long-term stability of CU traits showed this to be high over longer periods of time (i.e. 1 up to 53 years) [52, 115, 130-139]. Only a short-term study found stability to be low [140]. However, findings are comparable when no correction for conduct problems was made $[110,115,128]$ and when a correction was made [119-121, 123, 126, 127], indicating the presence of $\mathrm{CU}$ traits quite robustly predicting a poorer outcome over and above the presence of conduct problems. The reviewed studies provide no information regarding $\mathrm{CU}$ traits as a stand-alone construct.

\section{Criterion 4: Do CU traits show evidence of heritability from family and genetic studies?}

The next criterion to be met is whether it is possible to find evidence for a heritable nature of CU traits, supporting the hypothesis that $\mathrm{CU}$ traits are a valid entity, which can be delineated from environmentally caused psychopathology.

\section{Genetic influences}

Genetic factors contribute importantly to the expression of CU traits [131, 135, 141-146], although environmental factors play a small-to-moderate role as well $[131,135$, 142, 143, 145, 147] (see Table 6). Overlap with conduct problems is large, though not complete [145], indicating some room for unique genetic and environmental risk factors. High stability of $\mathrm{CU}$ traits seems to be related to high genetic influence [131, 135, 148], while antisocial behaviour seems to be more strongly related to unique environmental influences [142, 146, 147].

In recent studies, focus has not only been directed on phenotypes in twin studies, but also on molecular genetic underpinnings of $\mathrm{CU}$ traits as well. Up till now, the few genetic studies at a molecular level implicate multigenetic influences and a gene by environment interaction [149151]. Possible positive associations have been described for gene variants that affect monoamino oxidase A (MAO-A), catechol- $O$-methyltransferase (COMT) [150], and serotonin transporter (5HTT) $[150,151]$. None of these molecular genetic studies investigated $\mathrm{CU}$ traits outside either conduct problems or $\mathrm{CD}$, making it uncertain whether the genetic findings are specific for $\mathrm{CU}$ or more broadly associated with disruptive behaviour disorders (DBDs). 
Table 5 Characteristic course and outcome when CU traits are present in youth with conduct problems

\begin{tabular}{lll}
\hline Follow-up studies & Result & Support \\
\hline Short-term (0-4 years) & Social non-conformity $\uparrow$ & [44, 112, 120, 124] \\
& Days detained $\uparrow$ & \\
& Antisocial behaviour $\uparrow$ & \\
& Symptoms of psychopathology $\uparrow$ & \\
& Substance use $\uparrow$ & {$[122]$} \\
& Proactive aggression $\uparrow$ & {$[119,[118]$; non-significant } \\
& General and violent recidivism $\uparrow$ & {$[123]$ PCL:YV } \\
& Delinquency $\uparrow$ & {$[121]$} \\
& Seriousness charges $\uparrow$ & {$[110]$} \\
& Impairment $\uparrow$ & {$[61]$} \\
& Stability of CU traits & {$[115,130,134,137]$} \\
& Severeness and chronicity of antisocial & {$[127-129]$} \\
Long-term (4-12 years) & behaviour and delinquency $\uparrow$ & {$[125,126]$} \\
& Affiliation with deviant peers $\uparrow$ & {$[52,132,135,136,139]$} \\
\hline
\end{tabular}

[135], community twin sample; [52,133], community sample; $\uparrow$, increased in the presence of high CU traits; $\downarrow$, decreased in the presence of high $\mathrm{CU}$ traits

\section{Environmental influences}

Social and biological environmental factors play a small-tomoderate role as well (see Table 7). Parenting style is found to be negatively related to later developing CU traits [62, $133,152]$, as well as positive parenting was found to be related to decreased CU traits [130, 153]. Furthermore, maternal CU traits, resulting in parental hostility and parenting dysfunction, play an important role in the intergenerational continuity of maternal CU traits [152]. In contrast, others suggested that an ineffective parenting style is unrelated to the presence of callousness [154], or only for children with low levels of CU traits [108, 155-157]. Also it is suggested that high CU traits may lead to reduced monitoring behaviours of parents [121], increased parenting stress [158], decreased eye contact towards mothers [159], and to decreased parental involvement towards boys [130]. Furthermore, social economic status is generally found to be lower in children scoring high on CU traits $[62,115,133$, 160, 161]. Interestingly, prenatal risk factors such as maternal problems [62] and tobacco use [115] were found to be a significant predictor for $\mathrm{CU}$ traits as well. Finally, several studies indicate that traumatisation [109, 162-164], as well as disorganized attachment [165], and early institutional deprivation [166] can be related to CU traits as well. This leads to the overall impression that the role of environmental influences is present albeit somewhat inconsistent, which might be due to the correlational nature of these studies. Furthermore, only a few studies controlled statistically for conduct problems [114, 115, 152, 153], and none for $\mathrm{CD}$, making it uncertain whether the findings are completely accounted for by the presence of $\mathrm{CU}$ traits instead of conduct problems more generally. Nevertheless, social and biological environmental influences might play a role in CU traits co-occurring with $\mathrm{CD}$. Unknown is the role of the environment when CU traits exist independently of other psychiatric disorders.

\section{Criterion 5: Do CU traits have specific and differentiating neurobiological and neuropsychological correlates?}

The fifth criterion requires the presence of specific neurobiological correlates of a disorder [23]. Psychological tests, when shown to be reliable and reproducible, may also be considered laboratory studies in this context [22]. The literature on $\mathrm{CU}$ traits is too extensive to provide a detailed review. Nevertheless, we will provide a comprehensive summary (see Table 8).

\section{Neurobiological markers}

Studies on neurobiological markers are important to investigate whether it is possible to find neurobiological underpinnings for $\mathrm{CU}$ traits. Functional magnetic resonance imaging (fMRI) studies suggest impaired functioning of the amygdala [167, 168] and of the ventromedial prefrontal cortex (vmPFC) [169], as well as weaker functional connectivity between these two brain areas [168] in youth with conduct problems and CU traits, compared to healthy controls. The only fMRI study controlling for CD could not detect correlations with CU traits [170]. However, this study used only pictures of angry, sad and 


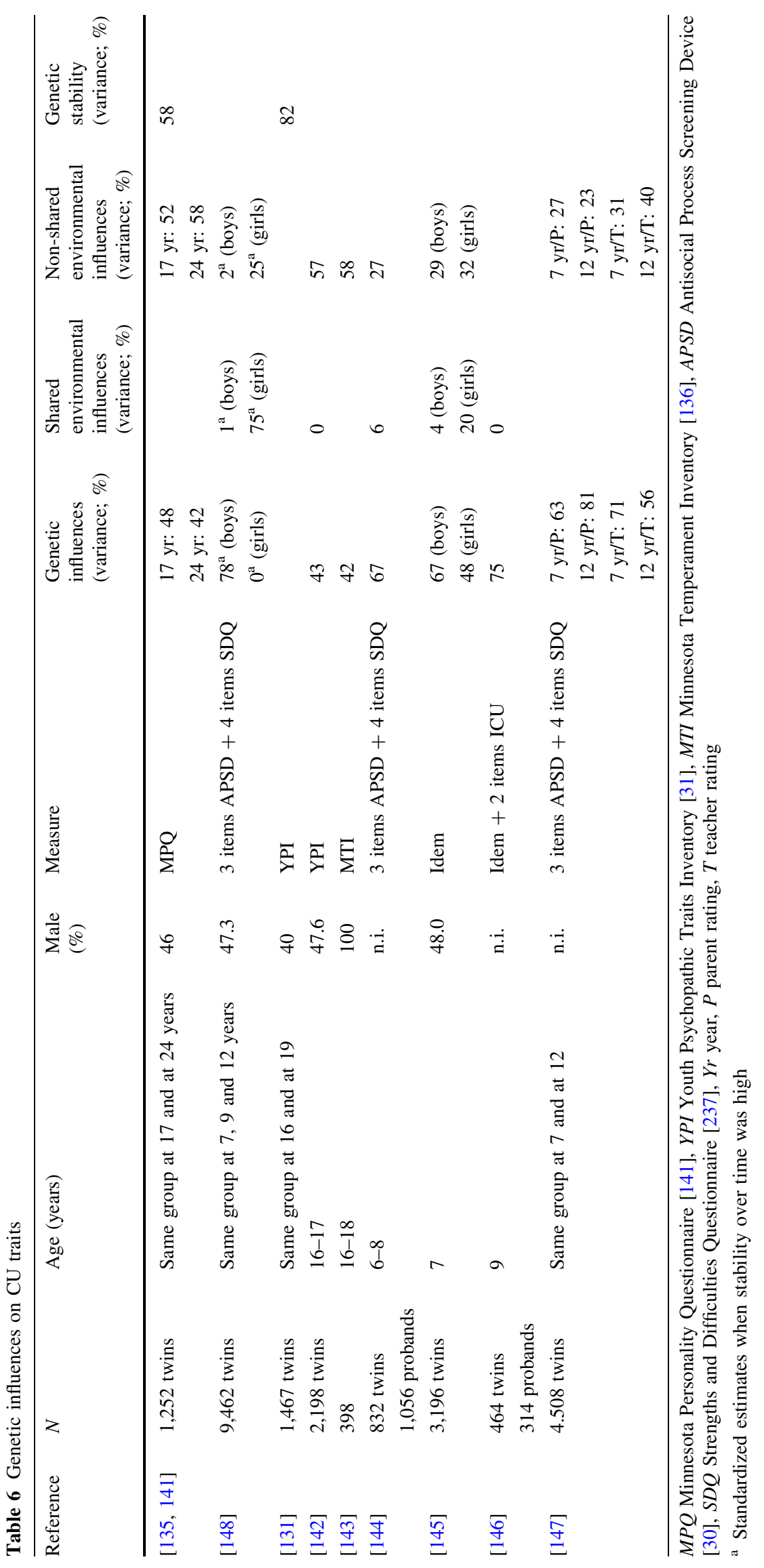


Table 7 Correlational environmental studies traits; + , positive correlation with $\mathrm{CU}$ traits

\begin{tabular}{lll}
\hline Type of environmental influence & Support & No support \\
\hline Parenting style (-) & {$[62,130,133,152,153,165,166]$} & {$[108,121,154-159]$} \\
SES $(-)$ & {$[62,115,133,160,161]$} & \\
Physical traumatization $(+)$ & {$[109,162-164]$} & \\
Prenatal risk $(+)$ & {$[62]$ Prenatal maternal problems } & \\
& {$[115]$ Exposure to cigarette smoke } & \\
\hline
\end{tabular}

Table 8 Neurobiological and neuropsychological studies on CU traits

\begin{tabular}{|c|c|c|c|}
\hline & Focus & Support & No support \\
\hline \multirow[t]{8}{*}{ Neurobiological markers } & fMRI: & [167-169] & [170] ? \\
\hline & Amgdala $\downarrow$ & & \\
\hline & vmPFC $\downarrow$ & & \\
\hline & sMRI: Amygdala = & [171] & \\
\hline & Cortisol $\downarrow$ & {$[76,115,173]$} & [172] ? \\
\hline & Testosteron $=$ & {$[173]$} & \\
\hline & Skin Conductance $\downarrow$ & {$[57,175,177,178]$} & \\
\hline & Heart rate $\downarrow$ & {$[174,176]$} & [52] Preschoolers \\
\hline \multirow[t]{4}{*}{ Prosocial reasoning } & Prosocial reasoning $\downarrow$ & [179-182] & {$[161,190,191] ?$} \\
\hline & $\begin{array}{l}\text { Cognitive, but not affective empathy } \\
\text { improves during growth }\end{array}$ & {$[94,95,189]$} & \\
\hline & $\begin{array}{l}\text { Egoistic functioning and acceptance of social } \\
\text { deviant behaviour }\end{array}$ & [183-185] & \\
\hline & $\begin{array}{l}\text { Positive labelling of aggression and } \\
\text { acceptance of social deviant behaviour }\end{array}$ & [186-188] & \\
\hline \multirow[t]{3}{*}{ Reward sensitivity } & Reward sensitivity $\uparrow$ & {$[81,161,184,192,193]$} & \\
\hline & Impulse inhibition $\downarrow$ & & \\
\hline & Punishment avoidance $\downarrow$ & & \\
\hline \multirow[t]{2}{*}{ Emotional reactivity } & Emotional reactivity $\downarrow$ & {$[52,56,164,194]$} & \\
\hline & Self-reported arousal $\downarrow$ & [83] & [195] \\
\hline \multirow[t]{2}{*}{ Emotion recognition } & Recognition of fear $\downarrow$ & [196-204] & \\
\hline & Recognition of sadness $\downarrow$ & {$[95,196,202,203,205,206]$} & \\
\hline
\end{tabular}

$\uparrow$, increased in the presence of high CU traits; $\downarrow$, decreased in the presence of high CU traits, =, no differences between high CU traits and control; ?, results inconsistent

neutral, but not fearful faces. As discussed below, decreased recognition of fearful faces is most strongly related to $\mathrm{CU}$ traits, compared to other types of faces. Furthermore, using structural MRI in a comparison between normal control children with children scoring high on conduct problems and CU traits increased grey matter in several brain areas, specifically in the PFC, has been found, but not in the amygdala [171].

As CU traits are associated with decreased anxiety, and cortisol levels are associated with anxiety levels, it is expected that increased $\mathrm{CU}$ traits correlate with decreased cortisol levels. One study could not detect this relationship, however probably because the level of CU traits was still low in the CU traits group [172]. In contrast, three studies did find blunted [76] or decreased baseline [115, 173] cortisol levels to correlate with CU traits.
Electrophysiological studies are important because CU traits are thought to relate to lower physiological arousal. Indeed, these studies show lower physiologic responsiveness in youth with $\mathrm{CU}$ traits, compared to youth without these traits, specifically in reaction to distress, and provocation [57, 120, 124, 174-178], although in preschoolers with high CU traits, higher overall physiological arousal was found [52].

Three studies controlled for CD [115, 170, 174], one for ODD [52], and several others for conduct problems [57, 76, 172, 173, 176-178]. Therefore, CU traits appear specifically related to the above-mentioned neurobiological abnormalities. Nevertheless, since no studies have examined neurobiological abnormalities in individuals with $\mathrm{CU}$ traits without any psychiatric disorders, it is difficult to infer conclusions about the relationship between neurobiological markers and CU traits outside CD. 
Prosocial reasoning

Studies on prosocial reasoning frequently use stories about hypothetical problematic social situations in which one has to solve moral dilemmas. Three studies specifically controlled for CD [94, 95, 179]. Less prosocial reasoning was found in youth with CD-high CU than in youth with CDlow CU and normal controls [179], while cognitive functioning seems to be unimpaired [94, 95]. Except for two [180, 181], the following studies controlled for conduct problems. Less prosocial reasoning was found as well in youth with conduct problems and high $\mathrm{CU}$ traits than in those with low CU traits [180-182], as well as more egoistically functioning, more problems in affective perspective taking, accepting more social deviant behaviour [183-185], and specifically aggression [186-188]. Furthermore, the presence of conduct problems together with CU traits has been associated with deficits in affective empathy, specifically for boys at different ages [95, 189], and improvement of cognitive empathy through the pubertal years [189]. A few studies seemed to find contradictory results, such as less reactivity and hostility [161], decreased expectations regarding the use of aggression [190], and more proactive behaviour [191] in the presence of high CU traits. However, these findings [161, 190, 191] can be explained by an increased orientation towards achieving ones goals. Thus, the reviewed studies support the notion of decreased affective prosocial reasoning in relation to increased $\mathrm{CU}$ traits over and above the relation of affective prosocial reasoning to conduct problems. However, virtually no information on prosocial reasoning is available regarding $\mathrm{CU}$ traits outside $\mathrm{CD}$.

\section{Reward sensitivity}

Findings on emotion processing have focussed on inhibition deficits, anxiety and response-to-distress as can be shown by psychological tests. These studies suggest a response modulation deficit in which a greater reward sensitivity, accompanied with decreased impulse inhibition and punishment avoidance play an important role when CU traits are high in youth with conduct problems [81, 161, 184, 192, 193]. These studies controlled for conduct problems, although not for $\mathrm{CD}$, suggesting abnormal reward sensitivity is related to the presence of $\mathrm{CU}$ traits over and above the presence of conduct problems. We found no studies regarding $\mathrm{CU}$ traits outside conduct problems.

\section{Emotional reactivity}

Emotional reactivity refers to the extent in which participants react to psychological discomfort. Four studies in youth with conduct problems [52, 56, 164, 194], with one controlling for CD [194], and one for ODD [52], suggest that $\mathrm{CU}$ traits are associated with lowered emotional reactivity in laboratory tests. In contrast, CU traits were not found to be associated with self-reported arousal in a community sample [195], although in a later study, based on the same community sample, high CU traits correlated with decreased self-reported arousal ratings to unpleasant pictures [83]. Thus, CU traits seem to be related to decreased emotional responsiveness, most likely over and above the presence of conduct problems.

\section{Emotion recognition}

In the presence of $\mathrm{CU}$ traits, the most consistent findings are impaired recognition of fearful faces in community youth [196-200], clinic referred youth [201], and youth with conduct problems [202, 203]. Directing attention to the eyes seems to improve facial emotion recognition [197, 198]. Furthermore, adolescents with conduct problems and high CU traits showed consistent impairments in eye contact to their parents, while higher levels of eye contact between fathers and their sons were associated with better fear recognition [204]. Findings on recognition of sadness are less consistent [95, 196, 202, 203, 205, 206]. All, but two studies [196, 200] controlled for conduct problems, and three for CD specifically [95, 203, 205], indicating that abnormal emotion recognition seems robustly associated with $\mathrm{CU}$ traits over and above the presence of abnormal emotion recognition in relation to conduct problems. Again, we found no studies regarding emotion recognition in $\mathrm{CU}$ traits outside conduct problems.

\section{Criterion 6: Do CU traits show a characteristic treatment response?}

Response to treatment is the last criterion when viewing the validity of a diagnosis. Accurate diagnosis is important, because it determines the success of treatment. Vice versa, the need for a specific treatment for a specific disorder confirms its validity. To date, there seem to be only few studies that focused on improving treatment response in youth with CU traits (see Table 9).

We found one study [207] applying a placebo-controlled treatment design. In this study, the response to behaviour modification with and without methylphenidate was examined. Boys with ADHD, conduct problems and high $\mathrm{CU}$ traits did not improve as much with behavioural therapy as those with low CU traits. However, when treated with methylphenidate, these differences largely disappeared, suggesting a beneficial effect of methylphenidate. 


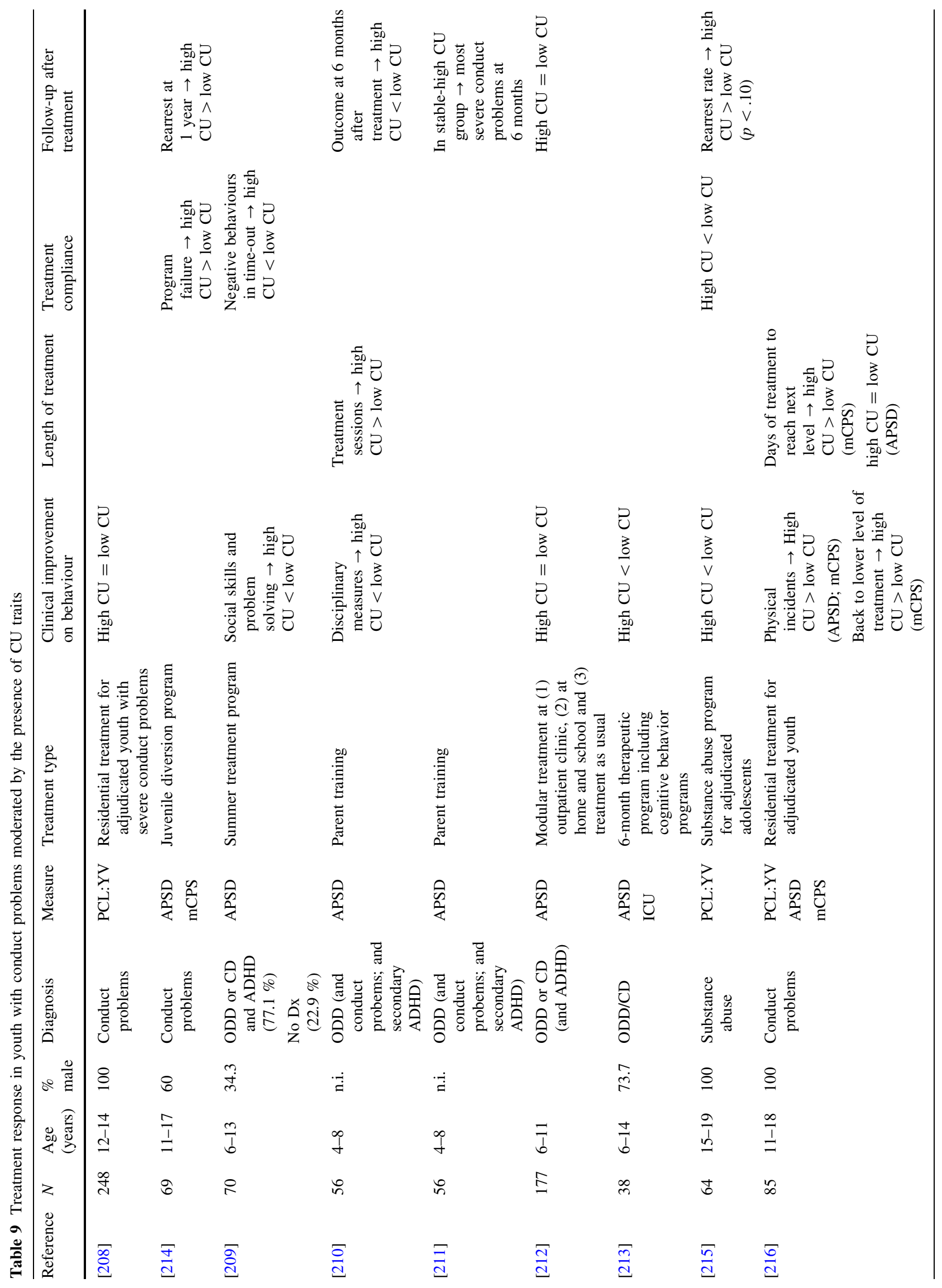




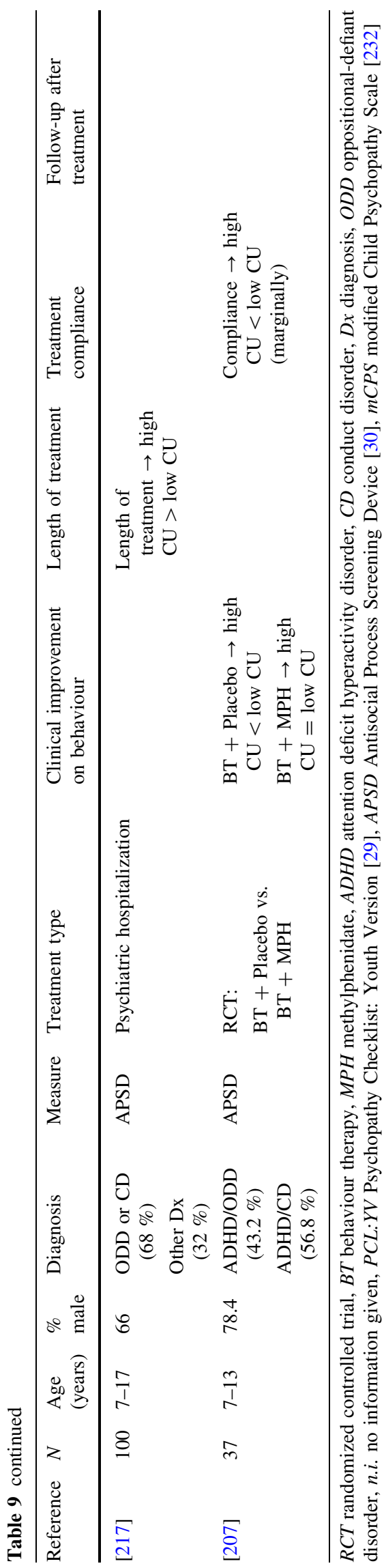

Other studies described treatment effects in open designs, of which seven explicitly controlled for conduct problems [207-213] or CD and ODD [207, 208, 211, 212]. Except two [208, 212], most open studies suggest a negative effect of CU traits, over and above conduct problems, on either treatment progress, outcome or follow-up [208-210, 213217]. Data are lacking on treatment effect of CU traits in the presence of other disorders than DBDs.

\section{Summary and conclusion}

This review examined the nosological status of CU traits by focusing on their validity in children and adolescents not only as a subtype of conduct disorder, but also as a potential classifier for other disorders or as a stand-alone construct. CU traits may moderate the treatment of disruptive behaviour disorders and the categorization of patients with these traits could be helpful in developing adequate therapeutic interventions. This topic was addressed by applying criteria for validation of psychiatric diagnoses, as formulated by Robins and Guze [22], and modified by Faraone [23].

Based on the reviewed studies, we conclude that the presence of CU traits can be assessed reliably as from school age, with preliminary data suggesting reliable assessment at preschool age as well. Although assessment measures are still in development, a consistent pattern of signs and symptoms is found demarcating it from other disorders. Furthermore, CU traits are associated with a distinct pattern of conduct problems in $\mathrm{CD}$, while there are indications that the same might be true for ODD and ADHD. That is, the presence of CU traits is related to a more aggressive and more pervasive kind of conduct problems. Similarly, CU traits can be distinguished from other psychiatric diagnoses in juveniles, such as autism spectrum disorder, mental retardation, personality disorder, substance abuse, and mood and anxiety disorders. In addition, there is a characteristic course and outcome: the presence of $\mathrm{CU}$ traits in youth with disruptive behaviour is increasingly stable with the increase of age and associated with increased levels of conduct problems, delinquency, reoffense and/or substance use over longer periods of time from childhood up to adulthood. Moreover, as antisocial behaviour decreases with aging, CU traits persist through life. In twin studies, genetic influences are shown to account for 43-81\% of CU traits. Furthermore, social and biological environmental influences such as poor parenting and traumatisation were found to cause a detrimental effect. Neurobiological and neuropsychological correlations can be found, in which findings indicate decreased prosocial reasoning, decreased responsiveness to distress cues, and decreased recognition of fearful and perhaps sad 
faces in youth with $\mathrm{CU}$ traits. Furthermore, in youth with conduct problems and high CU traits biological differences can be detected as well, such as impaired amygdala functioning, impaired functioning of the vmPFC, impaired connectivity between these two brain areas, as well as decreased cortisol levels and physiological arousal. Finally, treatment requires specific attention in the presence of $\mathrm{CU}$ traits: conduct problems are more severe at the start of the treatment, response to behavioural treatment is worse, and a more intensive treatment is required before improvement can be observed. Thus, there is clear supportive evidence for CU traits as a valid subtype of CD. Hence, we believe that $\mathrm{CU}$ traits are a valid and viable sub diagnosis, which give the opportunity to make an important differentiation especially in different kinds of conduct problems and antisocial behaviour. Moreover, given that the majority of studies were conducted in youth with conduct problems (i.e. ODD and CD grouped together) and several studies indicate that $\mathrm{CU}$ traits and ODD and to a lesser extent ADHD seem to be correlated as well, we believe CU traits may be a useful specifier for DBDs in general. No compelling evidence exists for $\mathrm{CU}$ traits as useful specifier in other psychiatric axis I and II disorders. Furthermore, although many of the above studies controlled for the presence of conduct problems, it still is difficult to mark $\mathrm{CU}$ traits as a stand-alone construct. Therefore, the question remains whether $\mathrm{CU}$ traits outside conduct problems constitute a clinical problem or not.

\section{Future research}

As this review covers a broad range of topics, related to the validity of $\mathrm{CU}$ traits, many issues for further research emerge. However, as others have pointed out the importance of further research to determine how the criteria for CU traits can be incorporated in the DSM in a valid and useful way [218, 219], in this paper we will specifically address points for future research concerning the validity of $\mathrm{CU}$ traits for DBDs in general and as a stand-alone construct.

This review shows that much research has been done in children and adolescents which supports the importance of distinguishing CU traits as an important symptom cluster in addition to conduct problems. We found many studies that combined youth with ODD and youth with CD into a single study group when investigating the moderating role of $\mathrm{CU}$ traits, mostly because ODD and CD are reasoned to reflect a single conduct domain (e.g. [136]). Nevertheless, there is still discussion whether these diagnoses represent the same underlying entity, and that ODD symptoms should not be seen as a milder, earlier presentation of CD [220]. Therefore, it is important to further investigate the relationship between CU traits and ODD specifically.
This leads us to another important issue. In the vast body of literature, we found only five studies, explicitly reporting on $\mathrm{CU}$ traits when scoring low on conduct problems $[61,75,126,127,161]$. As the findings from these studies are contradicting, and as the prevalence of $\mathrm{CU}$ traits in community samples seems to be relatively high, it seems to be important to direct further research on CU traits outside $\mathrm{CD}$, and in the absence of a disruptive disorder diagnosis. Thus, the relevance of CU traits over and beyond either CD and ODD will become much clearer. Through gathering clearer epidemiologic data, we might improve our knowledge about the overall prevalence of CU traits, identify aetiologic factors, and help to estimate the need for services [221].

Further research on the conceptualization of CU traits seems needed as well. Three issues seem to need further attention specifically. First, increased consensus about diagnostic criteria is needed. In this review, we encountered many different conceptualizations of $\mathrm{CU}$ traits. However, the proposal of Frick and Moffitt [19] to include $\mathrm{CU}$ traits as a specifier to the diagnosis of $\mathrm{CD}$ in de the upcoming DSM-5 is especially meaningful for this issue. Second, as there are indications for specific differences between boys and girls regarding either psychopathic or CU traits (e.g. [103, 222-224], gender issues seem to need more attention as well. Third, as Hong Kong children were found to have higher scores on CU traits than United States children [45], cultural issues might play an important role as well. Hence, it is important to invest in specification of diagnostic criteria, which take gender and cultural differences into account.

Effective treatment in youth could dramatically reduce violent incidents and victim injury [225]. Although promising results have been shown with interventions that aim at improving prosocial behaviour using positive reinforcement, either by parent training, training of individual social abilities, or medication, still there is a need for further randomized controlled treatment trials in youth with conduct problems and CU traits regarding short-term as well as long-term treatment effects. Also research seems to be warranted on the question whether specific treatment is needed in the presence of $\mathrm{CU}$ traits outside conduct problems.

Then there is the topic that, although several theories about developmental pathways regarding psychopathy and CU traits have been proposed [2, 164, 226], the ultimate causes in terms of gene-environmental interplay as well as (deviancies in) brain development have to be unravelled. This leads to several questions, such as whether it is possible to extract candidate genes for further genetic research, while new types of genetic research, such as imaging genetic work, seem to be promising in clarifying the role of specific endophenotypes [9]. However, as parenting 
practices are among the most powerful predictors of later outcomes in children and constitute opportunities for interventions [227], a next question is whether specific parenting practices at young age might decrease the further development of $\mathrm{CU}$ traits either in- and outside CD. Finally, the MRI studies raise further questions about the underpinnings of $\mathrm{CU}$ traits. Although it is hypothesized that there is a distinct brain development in boys with callous-unemotional conduct problems [171], this needs further exploration.

This review has focused on the diagnostic validity of $\mathrm{CU}$ traits in- and outside $\mathrm{CD}$. It becomes clear that $\mathrm{CU}$ traits have gained increasing attention in the past years, and our understanding on this topic increases steadily. However, much research is needed on the prevalence, aetiology, and need for diagnosis and treatment of $\mathrm{CU}$ traits outside $\mathrm{CD}$, to improve our understanding of $\mathrm{CU}$ traits as a cross-disorders construct and possibly as a stand-alone construct as well.

Open Access This article is distributed under the terms of the Creative Commons Attribution License which permits any use, distribution, and reproduction in any medium, provided the original author(s) and the source are credited.

\section{References}

1. Frick PJ, Ellis M (1999) Callous-unemotional traits and subtypes of conduct disorder. Clin Child Fam Psychol Rev 2:149-168

2. Salekin RT (2002) Psychopathy and therapeutic pessimism. Clinical lore or clinical reality? Clin Psychol Rev 22:79-112

3. Stickle TR, Frick PJ (2002) Developmental pathways to severe antisocial behavior: interventions for youth with callous/unemotional traits. Expert Rev Neurother 2:511-522

4. Herpertz SC, Sass H (2000) Emotional deficiency and psychopathy. Behav Sci Law 18:567-580

5. Salekin RT, Frick PJ (2005) Psychopathy in children and adolescents: the need for a developmental perspective. J Abnorm Child Psychol 33:403-409

6. Cleckley HM (1988) The mask of sanity. Mosby, St. Louis

7. Patrick CJ, Fowles DC, Krueger RF (2009) Triarchic conceptualization of psychopathy: developmental origins of disinhibition, boldness, and meanness. Dev Psychopathol 21:913-938

8. Patrick CJ (2010) Conceptualizing the psychopathic personality: disinhibited, bold, or just plain mean? In: Salekin RT, Lynam DR (eds) Handbook of child \& adolescent psychopathy. The Guilford Press, New York, pp 15-48

9. Jones AP, Viding E (2007) Psychopathic traits in young children. Neth J Psychol 63:117-125

10. Frick PJ (2007) Using the construct of psychopathy to understand antisocial and violent youth. In: Hervé H, Yuille JC (eds) The psychopath: theory, research and practice. Lawrence Erlbaum Associates, New Jersey

11. Johnstone L, Cooke DJ (2004) Psychopathic-like traits in childhood: conceptual and measurement concerns. Behav Sci Law 22:103-125

12. Rutter M (2005) Commentary: What is the meaning and utility of the psychopathy concept? J Abnorm Child Psychol 33:499-503
13. Edens JF, Skeem JL, Cruise KR, Cauffman E (2001) Assessment of "juvenile psychopathy" and its association with violence: a critical review. Behav Sci Law 19:53-80

14. Frick PJ, Marsee MA (2006) Psychopathy and developmental pathways to antisocial behavior. In: Patrick CJ (ed) Handbook of psychopathy. Guilford, New York, pp 353-375

15. Frick PJ, White SF (2008) Research review: the importance of callous-unemotional traits for developmental models of aggressive and antisocial behavior. J Child Psychol Psychiatry 49:359-375

16. Kotler JS, McMahon RJ (2005) Child psychopathy: theories, measurement, and relations with the development and persistence of conduct problems. Clin Child Fam Psychol Rev $8: 291-325$

17. Hart SD, Watt KA, Vincent GM (2002) Commentary on Seagrave and Grisso: impressions of the state of the art. Law Hum Behav 26:241-245

18. Seagrave D, Grisso T (2002) Adolescent development and the measurement of juvenile psychopathy. Law Hum Behav 26:219-239

19. Frick PJ, Moffitt TE (2010) A proposal to the DSM-V childhood disorders and the ADHD and disruptive behavior disorders work groups to include a specifier to the diagnosis of conduct disorder based on the presence of callous-unemotional traits. American Psychiatric Association, Washington, DC. http://www.dsm5. org/Proposed\%20Revision\%20Attachments/Proposal\%20for\% 20Callous $\% 20$ and $\% 20$ Unemotional $\% 20$ Specifier $\% 20$ of $\% 20$ Conduct\%20Disorder.pdf

20. Coid J, Freestone M, Ullrich S (2011) Subtypes of psychopathy in the British household population: findings from the national household survey of psychiatric morbidity. Soc Psychiatry Psychiatr Epidemiol Epidemiol. doi:10.1007/s00127-011-0395-3

21. Rutter M (2011) Child psychiatric diagnosis and classification: concepts, findings, challenges and potential. J Child Psychol Psychiatry 52:647-660

22. Robins E, Guze SB (1970) Establishment of diagnostic validity in psychiatric illness: its application to schizophrenia. Am J Psychiatry 126:983-987

23. Faraone SV (2005) The scientific foundation for understanding attention-deficit/hyperactivity disorder as a valid psychiatric disorder. Eur Child Adolesc Psychiatry 14:1-10

24. Andreasen NC (1995) The validation of psychiatric diagnosis: new models and approaches. Am J Psychiatry 152:161-162

25. Hofvander B, Ossowski D, Lundstrom S, Anckarsater H (2009) Continuity of aggressive antisocial behavior from childhood to adulthood: the question of phenotype definition. Int $\mathrm{J}$ Law Psychiatry 32:224-234

26. Cronbach LJ, Meehl PE (1955) Construct validity in psychological tests. Psychol Bull 52:281-302

27. Strauss ME (2005) Introduction to the special section on construct validity of psychological tests: 50 years after Cronbach and Meehl (1955). Psychol Assess 17:395

28. Krueger RF (1999) The structure of common mental disorders. Arch Gen Psychiatry 56:921-926

29. Forth AE, Kosson DS, Hare RD (2003) The Psychopathy Checklist: Youth Version. Multi-Health Systems, Toronto

30. Frick PJ, Hare RD (2001) The antisocial process screening device. Multi-Health Systems, Toronto

31. Andershed H, Kerr M, Stattin H, Kevander S (2002) Psychopathic traits in non-referred youths: initial test of a new assessment tool. In: Blaauw E, Sheridan L (eds) Psychopathscurrent international perspectives. Elsevier, Den Haag, pp 131158

32. Sharp C, Kine S (2008) The assessment of juvenile psychopathy: strengths and weaknesses of currently used questionnaire measures. Child Adolesc Ment Health 13:85-95 
33. Brandt JR, Kennedy WA, Patrick CJ, Curtin JJ (1997) Assessment of psychopathy in a population of incarcerated adolescent offenders. Psychol Assess 9:429-435

34. Frick PJ (1995) Callous-unemotional traits and conduct problems: a two-factor model of psychopathy in children. Issues Criminol Leg Psychol 24:47-51

35. Frick PJ, Bodin SD, Barry CT (2000) Psychopathic traits and conduct problems in community and clinic-referred samples of children: further development of the psychopathy screening device. Psychol Assess 12:382-393

36. Lexcen FJ, Vincent GM, Grisso T (2004) Validity and structure of a self-report measure of youth psychopathy. Behav Sci Law 22:69-84

37. Murrie DC, Marcus DK, Douglas KS, Lee Z, Salekin RT, Vincent G (2007) Youth with psychopathy features are not a discrete class: a taxometric analysis. J Child Psychol Psychiatry 48:714-723

38. Penney SR, Moretti MM, Da Silva KS (2008) Structural validity of the MACI psychopathy and narcissism scales: evidence of multidimensionality and implications for use in research and screening. J Clin Child Adolesc Psychol 37:422-433

39. Scholte EM, Stoutjesdijk R, Van Oudheusden MA, Lodewijks H, van der Ploeg JD (2010) Screening of egocentric and unemotional characteristics in incarcerated and community children. Int J Law Psychiatry $33: 164-170$

40. Neumann CS, Kosson DS, Forth AE, Hare RD (2006) Factor structure of the Hare Psychopathy Checklist: Youth Version (PCL: YV) in incarcerated adolescents. Psychol Assess 18:142-154

41. Pardini D, Obradovic J, Loeber R (2006) Interpersonal callousness, hyperactivity/impulsivity, inattention, and conduct problems as precursors to delinquency persistence in boys: a comparison of three grade-based cohorts. J Clin Child Adolesc Psychol 35:46-59

42. Salekin RT, Brannen DN, Zalot AA, Leistico AM, Neumann CS (2006) Factor structure of psychopathy in youth: testing the applicability of the new four factor model. Crim Justice Behav 33:135-157

43. Sevecke K, Pukrop R, Kosson DS, Krischer MK (2009) Factor structure of the Hare Psychopathy Checklist: Youth version in German female and male detainees and community adolescents. Psychol Assess 21:45-56

44. Dadds MR, Fraser J, Frost A, Hawes DJ (2005) Disentangling the underlying dimensions of psychopathy and conduct problems in childhood: a community study. J Consult Clin Psychol 73:400-410

45. Fung AL, Gao Y, Raine A (2010) The utility of the child and adolescent psychopathy construct in Hong Kong, China. J Clin Child Adolesc Psychol 39:134-140

46. Jones S, Cauffman E, Miller JD, Mulvey E (2006) Investigating different factor structures of the Psychopathy Checklist: Youth Version: confirmatory factor analytic findings. Psychol Assess 18:33-48

47. Kosson DS, Cyterski TD, Steuerwald BL, Neumann CS, Walker-Matthews S (2002) The reliability and validity of the Psychopathy Checklist: Youth Version (PCL:YV) in nonincarcerated adolescent males. Psychol Assess 14:97-109

48. Väfors FM, Ruchkin V, Koposov R, Af KB (2008) Antisocial process screening device: validation on a Russian sample of juvenile delinquents with the emphasis on the role of personality and parental rearing. Int J Law Psychiatry 31:438-446

49. Veen VC, Stevens GW, Andershed H, Raaijmakers QA, Doreleijers TA, Vollebergh WA (2011) Cross-ethnic generalizability of the three-factor model of psychopathy: The Youth Psychopathic Traits Inventory in an incarcerated sample of native Dutch and Moroccan immigrant boys. Int J Law Psychiatry $34: 127-130$
50. Vitacco MJ, Rogers R, Neumann CS (2003) The antisocial process screening device: an examination of its construct and criterion-related validity. Assess 10:143-150

51. Vitacco MJ, Neumann CS, Caldwell MF, Leistico AM, Van Rybroek GJ (2006) Testing factor models of the Psychopathy Checklist: Youth Version and their association with instrumental aggression. J Pers Assess 87:74-83

52. Willoughby MT, Waschbusch DA, Moore GA, Propper CB (2011) Using the ASEBA to screen for callous unemotional traits in early childhood: factor structure, temporal stability, and utility. J Psychopathol Behav Assess 33:19-30

53. Frick PJ (2004) The inventory of callous-unemotional traits. University of New Orleans, New Orleans

54. Decuyper M, De Clercq B, De Bolle M, De Fruyt F (2009) Validation of FFM PD counts for screening personality pathology and psychopathy in adolescence. J Pers Disord 23:587-605

55. Essau CA, Sasagawa S, Frick PJ (2006) Callous-unemotional traits in a community sample of adolescents. Assessment 13:454469

56. Kimonis ER, Frick PJ, Muñoz LC, Aucoin KJ (2007) Can a laboratory measure of emotional processing enhance the statistical prediction of aggression and delinquency in detained adolescents with callous-unemotional traits? J Abnorm Child Psychol 35:773-785

57. Kimonis ER, Frick PJ, Skeem JL, Marsee MA, Cruise K, Munoz LC, Aucoin KJ, Morris AS (2008) Assessing callous-unemotional traits in adolescent offenders: validation of the Inventory of Callous-Unemotional Traits. Int J Law Psychiatry 31:241252

58. Roose A, Bijttebier P, Decoene S, Claes L, Frick PJ (2010) Assessing the affective features of psychopathy in adolescence: a further validation of the inventory of callous and unemotional traits. Assessment 17:44-57

59. Rowe R, Maughan B, Moran P, Ford T, Briskman J, Goodman R (2010) The role of callous and unemotional traits in the diagnosis of conduct disorder. J Child Psychol Psychiatry 51:688-695

60. Kahn RE, Frick PJ, Youngstrom E, Findling RL, Youngstrom JK (2011) The effects of including a callous-unemotional specifier for the diagnosis of conduct disorder. J Child Psychol Psychiatry. doi:10.1111/j.1469-7610.2011.02463.x

61. Keenan K, Wroblewski K, Hipwell A, Loeber R, StouthamerLoeber M (2010) Age of onset, symptom threshold, and expansion of the nosology of conduct disorder for girls. J Abnorm Psychol 119:689-698

62. Barker ED, Oliver BR, Viding E, Salekin RT, Maughan B (2011) The impact of prenatal maternal risk, fearless temperament and early parenting on adolescent callous-unemotional traits: a 14-year longitudinal investigation. J Child Psychol Psychiatry 52:878-888

63. Frick PJ (2009) Extending the construct of psychopathy to youth: implications for understanding, diagnosing, and treating antisocial children and adolescents. Can J Psychiatry 54:803812

64. Crapanzano AM, Frick PJ, Terranova AM (2010) Patterns of physical and relational aggression in a school-based sample of boys and girls. J Abnorm Child Psychol 38:433-445

65. Crapanzano AM, Frick PJ, Childs K, Terranova AM (2011) Gender differences in the assessment, stability, and correlates to bullying roles in middle school children. Behav Sci Law 29:677-694

66. Fougere A, Potter S, Boutilier J (2009) Psychopathy and offence severity in sexually aggressive and violent youth. Crim Behav Ment Health 19:247-252

67. Kerr M, Van ZM, Stattin H (2011) Psychopathic traits moderate peer influence on adolescent delinquency. J Child Psychol Psychiatry. doi:10.1111/j.1469-7610.2011.02492.x 
68. Lawing K, Frick PJ, Cruise KR (2010) Differences in offending patterns between adolescent sex offenders high or low in callous-unemotional traits. Psychol Assess 22:298-305

69. Marsee MA, Barry CT, Childs KK, Frick PJ, Kimonis ER, Munoz LC, Aucoin KJ, Fassnacht GM, Kunimatsu MM, Lau KS (2011) Assessing the forms and functions of aggression using self-report: factor structure and invariance of the peer conflict scale in youths. Psychol Assess 23:792-804

70. O’Neill ML, Nenzel ME, Caldwell W (2009) Intrusive thoughts and psychopathy in a student and incarcerated sample. J Behav Ther Exp Psychiatry 40:147-157

71. Rucevic S (2010) Psychopathic personality traits and delinquent and risky sexual behaviors in Croatian sample of non-referred boys and girls. Law Hum Behav 34:379-391

72. Stickle TR, Marini VA, Thomas JN (2011) Gender differences in psychopathic traits, types, and correlates of aggression among adjudicated youth. J Abnorm Child Psychol. doi 10.1007/ s10802-011-9588-1

73. White SF, Cruise KR, Frick PJ (2009) Differential correlates to self-report and parent-report of callous-unemotional traits in a sample of juvenile sexual offenders. Behav Sci Law 27:910-928

74. Scholte EM, van der Ploeg JD (2007) The development of a rating scale to screen social and emotional detachment in children and adolescents. Int J Methods Psychiatr Res 16:137-149

75. Christian RE, Frick PJ, Hill NL, Tyler L, Frazer DR (1997) Psychopathy and conduct problems in children: II. Implications for subtyping children with conduct problems. J Am Acad Child Adolesc Psychiatry 36:233-241

76. Stadler C, Kroeger A, Weyers P, Grasmann D, Horschinek M, Freitag C, Clement HW (2011) Cortisol reactivity in boys with attention-deficit/hyperactivity disorder and disruptive behavior problems: the impact of callous unemotional traits. Psychiatry Res 187:204-209

77. Lynam DR (1996) Early identification of chronic offenders: who is the fledgling psychopath? Psychol Bull 120:209-234

78. Lynam DR (1998) Early identification of the fledgling psychopath: locating the psychopathic child in the current nomenclature. J Abnorm Psychol 107:566-575

79. Delisi M, Vaughn M, Beaver KM, Wexler J, Barth AE, Fletcher JM (2011) Fledgling psychopathy in the classroom: ADHD subtypes psychopathy, and reading comprehension in a community sample of adolescents. Youth Violence Juv Justice 9:43-58

80. Brammer WA, Lee SS (2011) Impairment in children with and without adhd: contributions from oppositional defiant disorder and callous-unemotional traits. J Atten Disord. doi:10.1177/ 1087054711403709

81. Barry CT, Frick PJ, DeShazo TM, McCoy MG, Ellis M, Loney BR (2000) The importance of callous-unemotional traits for extending the concept of psychopathy to children. J Abnorm Psychol 109:335-340

82. Fowler T, Langley K, Rice F, Whittinger N, Ross K, van Goozen S, Owen MJ, O'Donovan MC, van den Bree MB, Thapar A (2009) Psychopathy traits in adolescents with childhood attention-deficit hyperactivity disorder. $\mathrm{Br} \mathrm{J}$ Psychiatry 194:62-67

83. Michonski JD, Sharp C (2010) Revisiting Lynam's notion of the "fledgling psychopath": are HIA-CP children truly psychopathic-like? Child Adolesc Psychiatry Ment Health 4:24

84. Sevecke K, Kosson DS, Krischer MK (2009) The relationship between attention deficit hyperactivity disorder, conduct disorder, and psychopathy in adolescent male and female detainees. Behav Sci Law 27:577-598

85. Waschbusch DA, Willoughby MT (2008) Attention-deficit/ hyperactivity disorder and callous-unemotional traits as moderators of conduct problems when examining impairment and aggression in elementary school children. Aggress Behav 34:139153

86. Lynam DR, Derefinko KJ (2007) Psychopathy and personality. In: Patrick CJ (ed) Handbook of psychopathy. The Guilford Press, New York, pp 133-155

87. Lee Z, Salekin RT, Iselin AM (2010) Psychopathic traits in youth: is there evidence for primary and secondary subtypes? J Abnorm Child Psychol 38:381-393

88. Lynam DR, Caspi A, Moffitt TE, Raine A, Loeber R, Stouthamer-Loeber M (2005) Adolescent psychopathy and the big five: results from two samples. J Abnorm Child Psychol 33:431-443

89. Salekin RT, Leistico AM, Trobst KK, Schrum CL, Lochman JE (2005) Adolescent psychopathy and personality theory-the interpersonal circumplex: expanding evidence of a nomological net. J Abnorm Child Psychol 33:445-460

90. Sadeh N, Verona E, Javdani S, Olson L (2009) Examining psychopathic tendencies in adolescence from the perspective of personality theory. Aggress Behav 35:399-407

91. Barry CT, Frick PJ, Killian AL (2003) The relation of narcissism and self-esteem to conduct problems in children: a preliminary investigation. J Clin Child Adolesc Psychol 32:139-152

92. American Psychiatric Association (2000) Diagnostic and statistical manual of mental disorders, 4th edn. American Psychiatric Association, Washington, DC (revision)

93. Rogers J, Viding E, Blair RJ, Frith U, Happe F (2006) Autism spectrum disorder and psychopathy: shared cognitive underpinnings or double hit? Psychol Med 36:1789-1798

94. Jones AP, Happe FG, Gilbert F, Burnett S, Viding E (2010) Feeling, caring, knowing: different types of empathy deficit in boys with psychopathic tendencies and autism spectrum disorder. J Child Psychol Psychiatry 51:1188-1197

95. Schwenck C, Mergenthaler J, Keller K, Zech J, Salehi S, Taurines R, Romanos M, Schecklmann M, Schneider W, Warnke A, Freitag CM (2011) Empathy in children with autism and conduct disorder: group-specific profiles and developmental aspects. J Child Psychol Psychiatry. doi:10.1111/j.1469-7610.2011.02499.x

96. Fontaine N, Barker ED, Salekin RT, Viding E (2008) Dimensions of psychopathy and their relationships to cognitive functioning in children. J Clin Child Adolesc Psychol 37:690-696

97. Salekin RT, Neumann CS, Leistico AM, Zalot AA (2004) Psychopathy in youth and intelligence: an investigation of Cleckley's hypothesis. J Clin Child Adolesc Psychol 33:731742

98. Frick PJ, O’Brien BS, Wootton JM, McBurnett K (1994) Psychopathy and conduct problems in children. J Abnorm Psychol 103:700-707

99. Loney BR, Frick PJ, Ellis M, McCoy MG (1998) Intelligence, callous-unemotional traits, and antisocial behavior. J Psychopathol Behav Assess 20:231-247

100. Vaughn MG, Delisi M, Beaver KM, Wexler J, Barth A, Fletcher J (2011) Juvenile psychopathic personality traits are associated with poor reading achievement. Psychiatr Q 82:177-190

101. Dåderman AM, Edman G, Meurling AW, Levander S, Kristiansson M (2010) Flunitrazepam intake in male offenders. Nord J Psychiatry. doi:10.3109/08039488.2010.522730

102. Fritz MV, Wiklund G, Koposov RA, Af KB, Ruchkin VV (2008) Psychopathy and violence in juvenile delinquents: what are the associated factors? Int J Law Psychiatry 31:272-279

103. Hemphälä M, Tengström A (2010) Associations between psychopathic traits and mental disorders among adolescents with substance use problems. Br J Clin Psychol 49:109-122

104. Mailloux DL, Forth AE, Kroner DG (1997) Psychopathy and substance use in adolescent male offenders. Psychol Rep 81:529-530

105. Murrie DC, Cornell DG (2000) The Millon adolescent clinical inventory and psychopathy. J Pers Assess 75:110-125 
106. Dolan MC, Rennie CE (2007) Is juvenile psychopathy associated with low anxiety and fear in conduct-disordered male offenders? J Anxiety Disord 21:1028-1038

107. Frick PJ, Lilienfeld SO, Ellis M, Loney B, Silverthorn P (1999) The association between anxiety and psychopathy dimensions in children. J Abnorm Child Psychol 27:383-392

108. Hipwell AE, Pardini DA, Loeber R, Sembower M, Keenan K, Stouthamer-Loeber M (2007) Callous-unemotional behaviors in young girls: shared and unique effects relative to conduct problems. J Clin Child Adolesc Psychol 36:293-304

109. Pardini DA, Lochman JE, Powell N (2007) The development of callous-unemotional traits and antisocial behavior in children: are there shared and/or unique predictors? J Clin Child Adolesc Psychol 36:319-333

110. Pardini DA, Fite PJ (2010) Symptoms of conduct disorder, oppositional defiant disorder, attention-deficit/hyperactivity disorder, and callous-unemotional traits as unique predictors of psychosocial maladjustment in boys: advancing an evidence base for DSM-V. J Am Acad Child Adolesc Psychiatry 49:1134-1144

111. Polier GG, Herpertz-Dahlmann B, Matthias K, Konrad K, Vloet TD (2010) Associations between trait anxiety and psychopathological characteristics of children at high risk for severe antisocial development. Atten Defic Hyperact Disord 2:185-193

112. Kimonis ER, Skeem JL, Cauffman E, Dmitrieva J (2011) Are secondary variants of juvenile psychopathy more reactively violent and less psychosocially mature than primary variants? Law Hum Behav 35:381-391

113. Wareham J, Dembo R, Poythress NG, Childs K, Schmeidler J (2009) A latent class factor approach to identifying subtypes of juvenile diversion youths based on psychopathic features. Behav Sci Law 27:71-95

114. Skeem JL, Cauffman E (2003) Views of the downward extension: comparing the Youth Version of the Psychopathy Checklist with the Youth Psychopathic traits Inventory. Behav Sci Law 21:737-770

115. Burke JD, Loeber R, Lahey BB (2007) Adolescent conduct disorder and interpersonal callousness as predictors of psychopathy in young adults. J Clin Child Adolesc Psychol 36:334-346

116. Javdani S, Sadeh N, Verona E (2011) Suicidality as a function of impulsivity, callous-unemotional traits, and depressive symptoms in youth. J Abnorm Psychol 120:400-413

117. Corrado RR, Vincent GM, Hart SD, Cohen IM (2004) Predictive validity of the Psychopathy Checklist: Youth Version for general and violent recidivism. Behav Sci Law 22:5-22

118. Fite PJ, Stoppelbein L, Greening L (2009) Proactive and reactive aggression in a child psychiatric inpatient population. J Clin Child Adolesc Psychol 38:199-205

119. Frick PJ, Cornell AH, Barry CT, Bodin SD, Dane HE (2003) Callous-unemotional traits and conduct problems in the prediction of conduct problem severity, aggression, and self-report of delinquency. J Abnorm Child Psychol 31:457-470

120. Moran P, Rowe R, Flach C, Briskman J, Ford T, Maughan B, Scott S, Goodman R (2009) Predictive value of callousunemotional traits in a large community sample. J Am Acad Child Adolesc Psychiatry 48:1079-1084

121. Muñoz LC, Pakalniskiene V, Frick PJ (2011) Parental monitoring and youth behavior problems: moderation by callousunemotional traits over time. Eur Child Adolesc Psychiatry 20:261-269

122. Neumann CS, Vitacco M, Robertson A, Sewell K (2003) Longitudinal assessment of callous/impulsive traits, substance abuse, and symptoms of depression in adolescents: a latent variable approach. Ann N Y Acad Sci 1008:276-280

123. Salekin RT (2008) Psychopathy and recidivism from mid-adolescence to young adulthood: cumulating legal problems and limiting life opportunities. J Abnorm Psychol 117:386-395
124. Vitacco MJ, Neumann CS, Robertson AA, Durrant SL (2002) Contributions of impulsivity and callousness in the assessment of adjudicated male adolescents: a prospective study. J Pers Assess 78:87-103

125. Dandreaux DM, Frick PJ (2009) Developmental pathways to conduct problems: a further test of the childhood and adolescent-onset distinction. J Abnorm Child Psychol 37:375-385

126. Kimonis ER, Frick PJ, Barry CT (2004) Callous-unemotional traits and delinquent peer affiliation. J Consult Clin Psychol 72:956-966

127. Frick PJ, Stickle TR, Dandreaux DM, Farrell JM, Kimonis ER (2005) Callous-unemotional traits in predicting the severity and stability of conduct problems and delinquency. J Abnorm Child Psychol 33:471-487

128. McMahon RJ, Witkiewitz K, Kotler JS (2010) Predictive validity of callous-unemotional traits measured in early adolescence with respect to multiple antisocial outcomes. J Abnorm Psychol 119:752-763

129. Stockdale KC, Olver ME, Wong SC (2010) The Psychopathy Checklist: Youth Version and adolescent and adult recidivism: considerations with respect to gender, ethnicity, and age. Psychol Assess 22:768-781

130. Hawes DJ, Dadds MR, Frost AD, Hasking PA (2011) Do childhood callous-unemotional traits drive change in parenting practices? J Clin Child Adolesc Psychol 40:507-518

131. Forsman M, Lichtenstein P, Andershed H, Larsson H (2008) Genetic effects explain the stability of psychopathic personality from mid- to late adolescence. J Abnorm Psychol 117:606-617

132. Fontaine NM, McCrory EJ, Boivin M, Moffitt TE, Viding E (2011) Predictors and outcomes of joint trajectories of callousunemotional traits and conduct problems in childhood. $\mathrm{J}$ Abnorm Psychol 120:730-742

133. Frick PJ, Kimonis ER, Dandreaux DM, Farell JM (2003) The 4 year stability of psychopathic traits in non-referred youth. Behav Sci Law 21:713-736

134. Obradovic J, Pardini DA, Long JD, Loeber R (2007) Measuring interpersonal callousness in boys from childhood to adolescence: an examination of longitudinal invariance and temporal stability. J Clin Child Adolesc Psychol 36:276-292

135. Blonigen DM, Hicks BM, Krueger RF, Patrick CJ, Iacono WG (2006) Continuity and change in psychopathic traits as measured via normal-range personality: a longitudinal-biometric study. J Abnorm Psychol 115:85-95

136. Loney BR, Taylor J, Butler MA, Iacono WG (2007) Adolescent psychopathy features: 6-year temporal stability and the prediction of externalizing symptoms during the transition to adulthood. Aggress Behav 33:242-252

137. Lynam DR, Caspi A, Moffitt TE, Loeber R, Stouthamer-Loeber M (2007) Longitudinal evidence that psychopathy scores in early adolescence predict adult psychopathy. J Abnorm Psychol 116:155-165

138. Harpur TJ, Hare RD, Hakstian AR (1989) Two-factor conceptualization of psychopathy: construct validity and assessment implications. Psychol Assess 1:6-17

139. Harpur TJ, Hare RD (1994) Assessment of psychopathy as a function of age. J Abnorm Psychol 103:604-609

140. Lee Z, Klaver JR, Hart SD, Moretti MM, Douglas KS (2009) Short-term stability of psychopathic traits in adolescent offenders. J Clin Child Adolesc Psychol 38:595-605

141. Blonigen DM, Hicks BM, Krueger RF, Patrick CJ, Iacono WG (2005) Psychopathic personality traits: heritability and genetic overlap with internalizing and externalizing psychopathology. Psychol Med 35:637-648

142. Larsson H, Andershed H, Lichtenstein P (2006) A genetic factor explains most of the variation in the psychopathic personality. J Abnorm Psychol 115:221-230 
143. Taylor J, Loney BR, Bobadilla L, Iacono WG, McGue M (2003) Genetic and environmental influences on psychopathy trait dimensions in a community sample of male twins. J Abnorm Child Psychol 31:633-645

144. Viding E, Blair RJ, Moffitt TE, Plomin R (2005) Evidence for substantial genetic risk for psychopathy in 7-year-olds. J Child Psychol Psychiatry 46:592-597

145. Viding E, Frick PJ, Plomin R (2007) Aetiology of the relationship between callous-unemotional traits and conduct problems in childhood. Br J Psychiatry Suppl 49:s33-s38

146. Viding E, Jones AP, Frick PJ, Moffitt TE, Plomin R (2008) Heritability of antisocial behaviour at 9: do callous-unemotional traits matter? Dev Sci 11:17-22

147. Viding E, Fontaine NM, Oliver BR, Plomin R (2009) Negative parental discipline, conduct problems and callous-unemotional traits: monozygotic twin differences study. $\mathrm{Br} \mathrm{J}$ Psychiatry 195:414-419

148. Fontaine NMG, Rijsdijk FV, McCrory EJP, Viding E (2010) Etiology of different developmental trajectories of callousunemotional traits. J Am Acad Child Adolesc Psychiatry 49:656-664

149. Viding E, Hanscombe KB, Curtis CJ, Davis OS, Meaburn EL, Plomin R (2010) In search of genes associated with risk for psychopathic tendencies in children: a two-stage genome-wide association study of pooled DNA. J Child Psychol Psychiatry 51:780-788

150. Fowler T, Langley K, Rice F, van den Bree MB, Ross K, Wilkinson LS, Owen MJ, O'Donovan MC, Thapar A (2009) Psychopathy trait scores in adolescents with childhood ADHD: the contribution of genotypes affecting MAOA, 5HTT and COMT activity. Psychiatr Genet 19:312-319

151. Sadeh N, Javdani S, Jackson JJ, Reynolds EK, Potenza MN, Gelernter J, Lejuez CW, Verona E (2010) Serotonin transporter gene associations with psychopathic traits in youth vary as a function of socioeconomic resources. J Abnorm Psychol 119:604-609

152. Loney BR, Huntenburg A, Counts-Allan C, Schmeelk KM (2007) A preliminary examination of the intergenerational continuity of maternal psychopathic features. Aggress Behav 33:14-25

153. Pasalich DS, Dadds MR, Hawes DJ, Brennan J (2011) Do callous-unemotional traits moderate the relative importance of parental coercion versus warmth in child conduct problems? An observational study. J Child Psychol Psychiatry 52:1308-1315

154. Vitacco MJ, Neumann CS, Ramos V, Roberts MK (2003) Ineffective parenting: a precursor to psychopathic traits and delinquency in Hispanic females. Ann N Y Acad Sci 1008:300303

155. Edens JF, Skopp NA, Cahill MA (2008) Psychopathic features moderate the relationship between harsh and inconsistent parental discipline and adolescent antisocial behavior. J Clin Child Adolesc Psychol 37:472-476

156. Oxford M, Cavell TA, Hughes JN (2003) Callous/unemotional traits moderate the relation between ineffective parenting and child externalizing problems: a partial replication and extension. J Clin Child Adolesc Psychol 32:577-585

157. Wootton JM, Frick PJ, Shelton KK, Silverthorn P (1997) Ineffective parenting and childhood conduct problems: the moderating role of callous-unemotional traits. J Consult Clin Psychol 65:301-308

158. Fite PJ, Greening L, Stoppelbein L (2008) Relation between parenting stress and psychopathic traits among children. Behav Sci Law 26:239-248

159. Dadds MR, Allen JL, Oliver BR, Faulkner N, Legge K, Moul C, Woolgar M, Scott S (2011) Love, eye contact and the developmental origins of empathy v. psychopathy. Br J Psychiatry. doi:10.1192/bjp.bp.110.085720
160. Enebrink P, Andershed H, Långström N (2005) Callousunemotional traits are associated with clinical severity in referred boys with conduct problems. Nord J Psychiatry 59:431-440

161. Frick PJ, Cornell AH, Bodin SD, Dane HE, Barry CT, Loney BR (2003) Callous-unemotional traits and developmental pathways to severe conduct problems. Dev Psychol 39:246-260

162. Caputo AA, Frick PJ, Brodsky SL (1999) Family violence and juvenile sex offending: potential mediating roles of psychopathic traits and negative attitudes toward women. Crim Justice Behav 26:338-356

163. Krischer MK, Sevecke K (2008) Early traumatization and psychopathy in female and male juvenile offenders. Int $\mathrm{J}$ Law Psychiatry 31:253-262

164. Kimonis ER, Frick PJ, Muñoz LC, Aucoin KJ (2008) Callousunemotional traits and the emotional processing of distress cues in detained boys: testing the moderating role of aggression, exposure to community violence, and histories of abuse. Dev Psychopathol 20:569-589

165. Bohlin G, Eninger L, Brocki KC, Thorell LB (2011) Disorganized attachment and inhibitory capacity: predicting externalizing problem behaviors. J Abnorm Child Psychol. doi: 10.1007/s10802-011-9574-7

166. Kumsta R, Sonuga-Barke E, Rutter M (2011) Adolescent callous-unemotional traits and conduct disorder in adoptees exposed to severe early deprivation. $\mathrm{Br} \mathrm{J}$ Psychiatry. doi: 10.1192/bjp.bp.110.089441

167. Jones AP, Laurens KR, Herba CM, Barker GJ, Viding E (2009) Amygdala hypoactivity to fearful faces in boys with conduct problems and callous-unemotional traits. Am J Psychiatry 166:95-102

168. Marsh AA, Finger EC, Mitchell DG, Reid ME, Sims C, Kosson DS, Towbin KE, Leibenluft E, Pine DS, Blair RJ (2008) Reduced amygdala response to fearful expressions in children and adolescents with callous-unemotional traits and disruptive behavior disorders. Am J Psychiatry 165:712-720

169. Finger EC, Marsh AA, Mitchell DG, Reid ME, Sims C, Budhani S, Kosson DS, Chen G, Towbin KE, Leibenluft E, Pine DS, Blair JR (2008) Abnormal ventromedial prefrontal cortex function in children with psychopathic traits during reversal learning. Arch Gen Psychiatry 65:586-594

170. Passamonti L, Fairchild G, Goodyer IM, Hurford G, Hagan CC, Rowe JB, Calder AJ (2010) Neural abnormalities in early-onset and adolescence-onset conduct disorder. Arch Gen Psychiatry 67:729-738

171. De Brito SA, Mechelli A, Wilke M, Laurens KR, Jones AP, Barker GJ, Hodgins S, Viding E (2009) Size matters: increased grey matter in boys with conduct problems and callousunemotional traits. Brain 132:843-852

172. Poustka L, Maras A, Hohm E, Fellinger J, Holtmann M, Banaschewski T, Lewicka S, Schmidt MH, Esser G, Laucht M (2010) Negative association between plasma cortisol levels and aggression in a high-risk community sample of adolescents. J Neural Transm 117:621-627

173. Loney BR, Butler MA, Lima EN, Counts CA, Eckel LA (2006) The relation between salivary cortisol, callous-unemotional traits, and conduct problems in an adolescent non-referred sample. J Child Psychol Psychiatry 47:30-36

174. Anastassiou-Hadjicharalambous X, Warden D (2008) Physiologically-indexed and self-perceived affective empathy in conduct-disordered children high and low on callous-unemotional traits. Child Psychiatry Hum Dev 39:503-517

175. Blair RJR (1999) Responsiveness to distress cues in the child with psychopathic tendencies. Pers Individ Dif 27:135-145

176. De Wied M, van Boxtel A, Matthys W, Meeus W (2012) Verbal, facial and autonomic responses to empathy-eliciting film clips 
by disruptive male adolescents with high versus low callousunemotional traits. J Abnorm Child Psychol 40:211-223

177. Muñoz LC, Frick PJ, Kimonis ER, Aucoin KJ (2008) Verbal ability and delinquency: testing the moderating role of psychopathic traits. J Child Psychol Psychiatry 49:414-421

178. Muñoz LC, Frick PJ, Kimonis ER, Aucoin KJ (2008) Types of aggression, responsiveness to provocation, and callous-unemotional traits in detained adolescents. J Abnorm Child Psychol 36:15-28

179. Anastassiou-Hadjicharalambous X, Warden D (2008) Cognitive and affective perspective-taking in conduct-disordered children high and low on callous-unemotional traits. Child Adolesc Psychiatry Ment Health 2:16

180. Holmqvist R (2008) Psychopathy and affect consciousness in young criminal offenders. J Interpers Violence 23:209-224

181. Rogers R, Vitacco MJ, Jackson RL, Martin M, Collins M, Sewell KW (2002) Faking psychopathy? An examination of response styles with antisocial youth. J Pers Assess 78:31-46

182. Chandler M, Moran T (1990) Psychopathy and moral development: a comparative study of delinquent and nondelinquent youth. Dev Psychopathol 2:227-246

183. Blair RJR, Monson J, Frederickson N (2001) Moral reasoning and conduct problems in children with emotional and behavioural difficulties. Pers Individ Differ 31:799-811

184. Fisher L, Blair RJ (1998) Cognitive impairment and its relationship to psychopathic tendencies in children with emotional and behavioral difficulties. J Abnorm Child Psychol 26:511-519

185. Shulman EP, Cauffman E, Piquero AR, Fagan J (2011) Moral disengagement among serious juvenile offenders: a longitudinal study of the relations between morally disengaged attitudes and offending. Dev Psychol 47:1619-1632

186. Pardini DA, Lochman JE, Frick PJ (2003) Callous/unemotional traits and social-cognitive processes in adjudicated youths. J Am Acad Child Adolesc Psychiatry 42:364-371

187. Pardini DA, Byrd AL (2011) Perceptions of aggressive conflicts and others' distress in children with callous-unemotional traits: 'I'll show you who's boss, even if you suffer and I get in trouble'. J Child Psychol Psychiatry. doi:10.1111/j.1469-7610. 2011.02487.x

188. Stickle TR, Kirkpatrick NM, Brush LN (2009) Callousunemotional traits and social information processing: multiple risk-factor models for understanding aggressive behavior in antisocial youth. Law Hum Behav 33:515-529

189. Dadds MR, Hawes DJ, Frost AD, Vassallo S, Bunn P, Hunter K, Merz S (2009) Learning to 'talk the talk: the relationship of psychopathic traits to deficits in empathy across childhood. J Child Psychol Psychiatry 50:599-606

190. Lorber CM, Hughes TL, Miller JA, Crothers LM, Martin E (2010) Callous and unemotional traits and social cognitive processes in a sample of community-based aggressive youth. Int J Offender Ther Comp Criminol 55:1291-1307

191. Waschbusch DA, Walsh TM, Andrade BF, King S, Carrey NJ (2007) Social problem solving, conduct problems, and callousunemotional traits in children. Child Psychiatry Hum Dev 37:293-305

192. Blair RJR, Colledge E, Mitchell DG (2001) Somatic markers and response reversal: is there orbitofrontal cortex dysfunction in boys with psychopathic tendencies? J Abnorm Child Psychol 29:499-511

193. O’Brien BS, Frick PJ (1996) Reward dominance: associations with anxiety, conduct problems, and psychopathy in children. J Abnorm Child Psychol 24:223-240

194. Loney BR, Frick PJ, Clements CB, Ellis ML, Kerlin K (2003) Callous-unemotional traits, impulsivity, and emotional processing in adolescents with antisocial behavior problems. J Clin Child Adolesc Psychol 32:66-80
195. Sharp C, van Goozen S, Goodyer I (2006) Children's subjective emotional reactivity to affective pictures: gender differences and their antisocial correlates in an unselected sample of 7-11-yearolds. J Child Psychol Psychiatry 47:143-150

196. Blair RJR, Coles M (2000) Expression recognition and behavioral problems in early adolescence. Cogn Dev 15:421-434

197. Dadds MR, Perry Y, Hawes DJ, Merz S, Riddell AC, Haines DJ, Solak E, Abeygunawardane AI (2006) Attention to the eyes and fear-recognition deficits in child psychopathy. Br J Psychiatry 189:280-281

198. Dadds MR, El MY, Wimalaweera S, Guastella AJ (2008) Reduced eye gaze explains "fear blindness" in childhood psychopathic traits. J Am Acad Child Adolesc Psychiatry 47:455-463

199. Muñoz LC (2009) Callous-unemotional traits are related to combined deficits in recognizing afraid faces and body poses. J Am Acad Child Adolesc Psychiatry 48:554-562

200. Sylvers PD, Brennan PA, Lilienfeld SO (2011) Psychopathic traits and preattentive threat processing in children: a novel test of the fearlessness hypothesis. Psychol Sci 22:1280-1287

201. Leist T, Dadds MR (2009) Adolescents' ability to read different emotional faces relates to their history of maltreatment and type of psychopathology. Clin Child Psychol Psychiatry 14:237-250

202. Blair RJR, Budhani S, Colledge E, Scott S (2005) Deafness to fear in boys with psychopathic tendencies. J Child Psychol Psychiatry 46:327-336

203. Fairchild G, van Goozen SHM, Calder AJ, Stollery SJ, Goodyer IM (2009) Deficits in facial expression recognition in male adolescents with early-onset or adolescence-onset conduct disorder. J Child Psychol Psychiatry 50:627-636

204. Dadds MR, Jambrak J, Pasalich D, Hawes DJ, Brennan J (2011) Impaired attention to the eyes of attachment figures and the developmental origins of psychopathy. J Child Psychol Psychiatry 52:238-245

205. Fairchild G, Stobbe Y, van Goozen SH, Calder AJ, Goodyer IM (2010) Facial expression recognition, fear conditioning, and startle modulation in female subjects with conduct disorder. Biol Psychiatry 68:272-279

206. Woodworth M, Waschbusch D (2008) Emotional processing in children with conduct problems and callous/unemotional traits. Child Care Health Dev 34:234-244

207. Waschbusch DA, Carrey NJ, Willoughby MT, King S, Andrade $\mathrm{BF}$ (2007) Effects of methylphenidate and behavior modification on the social and academic behavior of children with disruptive behavior disorders: the moderating role of callous/unemotional traits. J Clin Child Adolesc Psychol 36:629-644

208. Caldwell MF (2011) Treatment-related changes in behavioral outcomes of psychopathy facets in adolescent offenders. Law Hum Behav 35:275-287

209. Haas SM, Waschbusch DA, Pelham WE Jr, King S, Andrade BF, Carrey NJ (2011) Treatment response in CP/ADHD children with callous/unemotional traits. J Abnorm Child Psychol 39:541-552

210. Hawes DJ, Dadds MR (2005) The treatment of conduct problems in children with callous-unemotional traits. J Consult Clin Psychol 73:737-741

211. Hawes DJ, Dadds MR (2007) Stability and malleability of callous-unemotional traits during treatment for childhood conduct problems. J Clin Child Adolesc Psychol 36:347-355

212. Kolko DJ, Pardini DA (2010) ODD dimensions, ADHD, and callous-unemotional traits as predictors of treatment response in children with disruptive behavior disorders. J Abnorm Psychol 119:713-725

213. Masi G, Manfredi A, Milone A, Muratori P, Polidori L, Ruglioni L, Muratori F (2011) Predictors of nonresponse to psychosocial treatment in children and adolescents with disruptive behavior disorders. J Child Adolesc Psychopharmacol 21:51-55 
214. Falkenbach DM, Poythress NG, Heide KM (2003) Psychopathic features in a juvenile diversion population: reliability and predictive validity of two self-report measures. Behav Sci Law 21:787-805

215. O’Neill ML, Lidz V, Heilbrun K (2003) Adolescents with psychopathic characteristics in a substance abusing cohort: treatment process and outcomes. Law Hum Behav 27:299-313

216. Spain SE, Douglas KS, Poythress NG, Epstein M (2004) The relationship between psychopathic features, violence and treatment outcome: the comparison of three youth measures of psychopathic features. Behav Sci Law 22:85-102

217. Stellwagen KK, Kerig PK (2010) Relation of callous-unemotional traits to length of stay among youth hospitalized at a state psychiatric inpatient facility. Child Psychiatry Hum Dev 41:251-261

218. Moffitt TE, Arseneault L, Jaffee SR, Kim-Cohen J, Koenen KC, Odgers CL, Slutske WS, Viding E (2008) Research review: DSM-V conduct disorder: research needs for an evidence base. J Child Psychol Psychiatry 49:3-33

219. Pardini DA, Frick PJ, Moffitt TE (2010) Building an evidence base for DSM-5 conceptualizations of oppositional defiant disorder and conduct disorder: introduction to the special section. J Abnorm Psychol 119:683-688

220. Diamantopoulou S, Verhulst FC, Van der Ende J (2011) The parallel development of ODD and CD symptoms from early childhood to adolescence. Eur Child Adolesc Psychiatry 20:301309

221. Robins LN (1990) Psychiatric epidemiology—a historic review. Soc Psychiatry Psychiatr Epidemiol 25:16-26

222. Odgers CL, Moretti MM, Reppucci ND (2005) Examining the science and practice of violence risk assessment with female adolescents. Law Hum Behav 29:7-27

223. Sevecke K, Lehmkuhl G, Krischer MK (2009) Examining relations between psychopathology and psychopathy dimensions among adolescent female and male offenders. Eur Child Adolesc Psychiatry 18:85-95

224. Sevecke K, Lehmkuhl G, Krischer MK (2010) Psychopathy, temperament and antisocial behaviour in girls. Z Kinder Jugendpsychiatr Psychother 38:91-101
225. Coid J, Yang M (2011) The impact of psychopathy on violence among the household population of Great Britain. Soc Psychiatry Psychiatr Epidemiol 46:473-480

226. Blair RJR, Peschardt KS, Budhani S, Mitchell DG, Pine DS (2006) The development of psychopathy. J Child Psychol Psychiatry 47:262-276

227. Loeber R, Farrington DP (2000) Young children who commit crime: epidemiology, developmental origins, risk factors, early interventions, and policy implications. Dev Psychopathol 12:737762

228. Hare RD (1991) Hare psychopathy checklist-revised (PCL-R) technical manual. Multi-Health Systems, Toronto

229. Hare RD (1991) The self-report psychopathy scale-II. University of British Columbia, Vancouver (unpublished test)

230. Hart SD, Cox DN, Hare RD (1995) Manual for the psychopathy checklist: screening version (PCL:SV). Multi-Health Systems, Toronto

231. Rogers R (1996) Survey of Attitudes and Life Experiences (SALE). University of North Texas, Denton (unpublished test)

232. Lynam DR (1997) Pursuing the psychopath: capturing the fledgling psychopath in a nomological net. J Abnorm Psychol 106:425-438

233. Frick PJ, Hare RD (2000) The Psychopathy Screening Device. Multi-Health Systems, Toronto unpublished Test

234. Cauffman E, Kimonis ER, Dmitrieva J, Monahan KC (2009) A multimethod assessment of juvenile psychopathy: comparing the predictive utility of the PCL:YV, YPI, and NEO PRI. Psychol Assess 21:528-542

235. Edens JF, Marcus DK, Vaughn MG (2011) Exploring the taxometric status of psychopathy among youthful offenders: is there a juvenile psychopath taxon? Law Hum Behav 35:13-24

236. Myers WC, Burket RC, Harris HE (1995) Adolescent psychopathy in relation to delinquent behaviors, conduct disorder, and personality disorders. J Forensic Sci 40:435-439

237. Goodman R (1997) The Strengths and Difficulties Questionnaire: a research note. J Child Psychol Psychiatry 38:581-586 